\title{
Antagonistic pattern of yeast species against some selected food-borne pathogens
}

\author{
Ilesanmi Festus Fadahunsi ${ }^{*}$ [D and Simbo Olubodun
}

\begin{abstract}
Background: The efficiency of synthetic preservation in shelf life extension of food is well documented, but the hazardous side effects associated with it are posing serious threat to the food industry. Therefore, this present research work is aimed at determining the suitability of yeast metabolite as an alternative natural preservative agent of food.

Results: The results obtained revealed that seventy-three yeast isolates were obtained from the fruits and were identified as Candida pelliculosa, Kluyveromyces phaffii, Metschnikowia pulcherrima, Saccharomyces cerevisiae 001, Saccharomyces cerevisiae 002, Saccharomyces cerevisiae 003 and Rhodotorula mucilaginosa and were confirmed safe. The highest production of lactic acid (3.6) and diacetyl $(1.0 \mathrm{mg} / \mathrm{ml})$ was recorded by Saccharomyces cerevisiae 001 and the best $\mathrm{pH}$, temperature, sodium chloride concentration, carbon and nitrogen sources that stimulated maximum inhibitory activities of the yeast species against the food-borne pathogens were $4,30^{\circ} \mathrm{C}, 2-4 \%$, glucose and skimmed milk, respectively. The lowest MIC and MBC values recorded were $3.125 \pm 0.6$ and $6.25 \pm 0.26 .25 \pm 0.3 \mu \mathrm{g} / \mathrm{ml}$, respectively.
\end{abstract}

Conclusion: The study confirmed that the combination of the yeast metabolites could be potentially used as biopreservation in food.

Keywords: Antagonistic pattern, Yeast species, Food-borne pathogens, Yeast metabolites, Zone of inhibition

\section{Background}

Yeast species are vividly grouped into the fungal kingdom based on the possession of a chitinous well-defined cell wall. They are unicellular eukaryotic fungi devoid of peptidoglycan with lipid-linked ester. Morphologically, they vary from round to ovoid, $5-10 \mu \mathrm{m}$ in diameter and exhibit both asexual and asexual modes of reproduction (Kurtzman et al. 2010, 2011). They are isolated from sugar-rich environments, skins of fruits, fermented foods and exudates of plants (Slavikova et al. 2007). In addition, they are resident in humans toe as part of skin flora, gut flora of mammals, some insects and deep sea environment, but the ecological function and biodiversity of yeast species are relatively unknown compared to other micro-organisms (Kutty et al. 2008; Herrera et al. 2010). There are documented reports on their survival in both

*Correspondence: sanmifadahunsi@yahoo.com Department of Microbiology, Faculty of Science, University of Ibadan, Ibadan, Oyo State, Nigeria aerobic and anaerobic environments (Balasubramanian 2004) and are known biochemically as non-lactose and cellobiose fermenters. They have been reported to survive a temperature range of $5-35{ }^{\circ} \mathrm{C}$ and freezing under certain conditions with decreasing viability per time (Arthur and Watson 1976). Yeast can either exist in free state or constitute synergy such as parasitism, symbiosis, mutualism and competition with other micro-organisms (Goldman 2008). Nutritionally, their complete growth requirement is simple, which comprises carbon, a nitrogen source (ammonium salt, nitrate, amino acid, peptide, urea, purine and pyrimidine), phosphate, sulphate, trace amount of potassium, magnesium, calcium, iron, zinc and a vitamin source such as biotin, thiamine, pantothenic acid (Deak 2006). It had been reported that yeast species secrete some inhibitory compounds such as diacetyl, organic acids, mycocins, antibiotic factors, volatile acids and various other products, which are capable of eliciting inhibition against food-borne pathogens and food spoilage micro-organisms, but the mechanism of 
inhibition is unknown (Oyewole 1997; Viljoen 2006). According to Druvefors et al. (2005), food fermentations are naturally carried out by an interacting complex microbial population comprising of bacteria, mould and yeast. It is important to note that reports on the production of allergy-causing spores and mycotoxins by yeast are unavailable, but the synthesis of antimicrobial metabolites is well documented, and these special attributes accord them their acceptability as biopreservative agent and starter cultures in food fermentation (Druvefors et al. 2005). Similarly, Hara et al. (1980), Pfeiffer and Radler (1984), Seki et al. (1985), Boone et al. (1990), Van Vuuren and Jacobs (1992), Comitini et al. (2004a, b) reported that genetically improved antagonistic yeast starter cultures contribute to improved safety of food, sensory qualities and shelf life of the finished product when inoculated into the fermenting medium by inhibiting the growth of associated pathogenic bacteria. According to Young (1987) and Boone et al. (1990), starter yeasts inhibit wild and undesirable yeast strains during beer and bread production. In addition, they also inhibit the growth of undesirable yeast during food preservation (Palpacelli et al. 1991) and as a therapeutic agent (Cailliez et al. 1994). From past research findings, it is observed that most of its applications are based on exploiting its antagonistic capabilities (Zhao et al. 2020). Summarily, it is used in food and agriculture for producing microbiologically stable fermented food products with good organoleptic properties, biocontrol agents for soil treatment and prevention of preand post-harvest diseases of crops (Pretorius 2000). In addition, Candida oleophila has been registered as a standard bio-control agent for post-harvest crop diseases (Entlaeshawy and Wilson 1997; Santos and Marquina 2004). It could be suggested that antagonistic yeasts could be a potential alternative bio-preservative to conventional chemical preservatives, which presently constitute threats to human lives (Chiquette 2009). There is an increasing interest in utilizing probiotic micro-organisms for treating gastrointestinal tract (GIT) disorders and yeast strains acting as antagonists toward spoilage or pathogenic microbes (O'sullivan et al. 2010; Maccaferri et al. 2012; Fernández et al. 2015). In addition, probiotic yeasts have shown inhibitory activity against pathogenic bacteria. Kumura et al. (2014), Psani and Kotzekidou (2006), Klingberg et al. (2005), Generoso et al. (2010) had reported the wide use of yeast species in probiotic preparations, and several studies have confirmed the positive interaction of yeast with probiotic bacteria by enhancing their survival and stimulating their growth (Hodgson et al. 1995; Katakura et al. 2010; Suharaja et al. 2012). Kelsesidis and Pothoulakis (2012) had reported the application of yeast metabolites in treatment of diarrhoea and candidiasis. Furthermore, Kurtzman et al. (2011) confirmed the effectiveness of yeast single cell protein in accelerating growth and conferring health benefits to cattle when fed into them.

Therefore, this present study is aimed at providing additional information on the antimicrobial property of yeast species against food-borne pathogens, which constitute serious public health problems in both developed and developing nations.

\section{Methods}

\section{Sample collection}

Apple, oranges, mango, pawpaw, watermelon, cashew and pineapple were purchased from various locations within Ibadan, Oyo state, Nigeria, in May 2020. The juice of each fruit was obtained using juice extractor and was used for isolation of yeast species in the laboratory.

\section{Test organisms}

The test bacteria used in this research were Salmonella $s p$ (S.S), Campylobacter jejuni (C.J), Listeria monocytogenes (L.M) PCM2191 and Vibrio cholera (V.C). The Salmonella sp and Vibrio cholerae were obtained from the culture collection of the Food Microbiology Unit, Department of Microbiology, University of Ibadan, while the Campylobacter jejuni was obtained from the Department of Veterinary Public Health and Preventive Medicine, University of Ibadan. The Listeria monocytogenes PCM2191 was obtained from Dr I.F. Fadahunsi of the Department of Microbiology, University of Ibadan. The indicator bacteria were subcultured repeatedly to obtain pure cultures, which were stored on agar slants in macAnthony bottles and kept in a refrigerator at $4{ }^{\circ} \mathrm{C}$.

\section{Isolation of yeast species from the food items}

This was carried out by weighing $10 \mathrm{~g}$ of the juice of each sample into $90 \mathrm{mls}$ of sterilized distilled water in 150ml Erlenmeyer flasks, and serial dilution was carried out according to the method described by Meynell and Meynell (1965). The malt extract agar plate containing $50 \mu \mathrm{g} / \mathrm{ml}$ Streptomycin was inoculated with $0.1 \mathrm{ml}$ from the $10^{-5}$ dilution test tube of the sample using the spread plate method and incubated at $30{ }^{\circ} \mathrm{C}$ for $72 \mathrm{~h}$. The plates were examined for microbial growth, and representative colonies were selected and subcultured repeatedly, until pure cultures were obtained and stored on malt extract agar slant in McCartney bottles and kept at $4{ }^{\circ} \mathrm{C}$ in a refrigerator. This treatment was repeated for the other fruit samples. 


\section{Pathogenicity test \\ Gelatin liquefaction}

One ml from 24-h-old culture of the yeast cells suspension was inoculated into sterile gelatin medium in 100-ml Erlenmeyer flasks containing 10\% malt extract and incubated at $30{ }^{\circ} \mathrm{C}$ for 7 days; the temperature was reduced to observe liquefaction. At lower temperature, liquefaction of gelatin indicates positive reaction, while un-liquefied gelatin indicates negative reaction (Walt and Yarrow 1984).

\section{Haemolysis test}

A colony from 24-h-old culture of the yeast cells was streaked on blood agar plates and incubated for 24-72 $\mathrm{h}$ at $30^{\circ} \mathrm{C}$ and were observed for alpha, beta or gamma haemolytic reaction (Olutiola et al. 1991).

\section{DNASE test}

The method described by Olutiola et al. (1991) was adopted by picking a colony from a 24-h-old culture of yeast cells and streaked on DNase agar plates containing methyl green indicator and incubated at $37^{\circ} \mathrm{C}$ for $72 \mathrm{~h}$. The plate was observed for green colour fades surrounded by a colourless zone.

\section{Characterization of yeast isolates from food items}

All the isolates were characterized based on their ability to assimilate carbon, nitrogen compounds and subjecting them to physiological tests as described by Sanni and Lonner (1993).

\section{Preparation of cell-free metabolites of the isolated yeast species}

One $\mathrm{ml}\left(1.0 \times 10^{7} \mathrm{cfu} / \mathrm{ml}\right)$ of a 48 -h-old yeast cells suspension was inoculated into $100 \mathrm{ml}$ of sterilized yeast extract peptone dextrose broth (YEPD) in 150-ml Erlenmeyer flask and incubated for $72 \mathrm{~h}$. Centrifugation was carried out for $15 \mathrm{~min}$ at $2800 \mathrm{rpm}$ to obtain the supernatant, which was used to determine the antimicrobial activity of the yeast species.

\section{Quantitative measurement of inhibitory compounds produced by the yeast species \\ Lactic acid}

Three drops of phenolphthalein indicator were added to $25 \mathrm{ml}$ of each supernatant, in 150-ml Erlenmeyer flask, and titrated against $0.1 \mathrm{M}$ sodium hydroxide until a pink colour appeared. One $\mathrm{ml}$ of $0.1 \mathrm{M}$ sodium hydroxide solution is equivalent to $90.80 \mathrm{~g}$ of lactic acid (AOAC 2003).

\section{Diacetyl}

This was done by transferring $25 \mathrm{ml}$ of the supernatant into $150-\mathrm{ml}$ Erlenmeyer flask containing $7.5 \mathrm{ml}$ of hydroxylamine solution, and $0.1 \mathrm{M}$ hydrochloric acid $(\mathrm{HCl})$ was gradually added to the flask until greenishyellow end point was reached using bromophenol blue as an indicator. The equivalent factor of $\mathrm{HCl}$ to diacetyl is $21.5 \mathrm{mg}$ (AOAC 2003).

\section{Preparation of inoculums}

A 24-h-old bacterial cell suspension of the indicator organisms was differently transferred into $5 \mathrm{ml}$ of normal saline, and the density of the inoculums was adjusted to 0.5 McFarland turbidity standards, resulting in a suspension of $1.0 \times 10^{7} \mathrm{cfu} / \mathrm{ml}$ of each of the test bacteria (Bhalodia and Shukla 2011).

\section{Determination of antagonistic activity of the cell free metabolite of the yeast species}

Mueller-Hinton agar was poured aseptically into the plates, which were previously seeded with the different standardized test bacteria, and wells were bored aseptically in the agar using 6-mm cork borer and filled with the different yeast metabolite. The plates were allowed to stay at $30{ }^{\circ} \mathrm{C}$ for $30 \mathrm{~min}$ to allow diffusion of the yeast metabolite into the agar and incubated at $30{ }^{\circ} \mathrm{C}$ for $24 \mathrm{~h}$. Zones of inhibition around the wells were measured in millimetre.

\section{Preparation of basal medium used for supplementation study}

The basal medium used for this study consisted of magnesium sulphate hepta-hydrate $\mathrm{MgSO}_{4} \cdot 7 \mathrm{H}_{2} \mathrm{O}(0.05 \mathrm{~g})$, potassium dihydrogen phosphate $\mathrm{KH}_{2} \mathrm{PO}_{4}(0.05 \mathrm{~g})$, potassium nitrate $(1.5 \mathrm{~g})$ in $1 \mathrm{~L}$ sterile distilled water in 2-L Erlenmeyer flask.

\section{Effect of $\mathrm{pH}$ on the antimicrobial activity of the cell-free metabolite of the yeast species}

Twenty $\mathrm{mls}$ of the yeast extract peptone dextrose medium (YEPD) at $\mathrm{pH} \mathrm{3,} \mathrm{4,} 6$ and 7 was dispensed into several $50-\mathrm{ml}$ Erlenmeyer flasks and sterilized at $121{ }^{\circ} \mathrm{C}$ for $15 \mathrm{~min}$ and inoculated with one $\mathrm{ml}\left(1.0 \times 10^{7} \mathrm{cfu} /\right.$ $\mathrm{ml}$ ) of a 48-h-old cells suspension of yeast species. Incubation and centrifugation were carried out as described earlier, and antimicrobial property was determined using the cell-free metabolite as described earlier (Singh et al. 2012). 
Effect of temperature on the antimicrobial activity of cell-free metabolite of the yeast species

Twenty mls of the yeast extract peptone dextrose medium (YEPD) was dispensed into several $50-\mathrm{ml}$ Erlenmeyer flasks, sterilized at $121{ }^{\circ} \mathrm{C}$ for $15 \mathrm{~min}$ and inoculated with one $\mathrm{ml}\left(1.0 \times 10^{7} \mathrm{cfu} / \mathrm{ml}\right)$ of a 48 -h-old cells suspension of the yeast species. Incubation and centrifugation were carried out as described earlier, and the supernatant obtained was dispensed in equal amount into various test tubes and differently incubated at $30{ }^{\circ} \mathrm{C}, 35^{\circ} \mathrm{C}, 40{ }^{\circ} \mathrm{C}$ and $45^{\circ} \mathrm{C}$. The antimicrobial activity was determined as described earlier (Singh et al. 2012).

\section{Effect of sodium chloride concentration} on the antimicrobial activity of the cell-free metabolite of the yeast species

Twenty mls of the basal medium was dispensed into several 50-ml Erlenmeyer flasks, and 2\%, 4\% and 6\% $\mathrm{NaCl}(\mathrm{w} / \mathrm{v})$ were differently added. Sterilization was carried out at $121{ }^{\circ} \mathrm{C}$ for $15 \mathrm{~min}$ and inoculated with one $\mathrm{ml}\left(1.0 \times 10^{7} \mathrm{cfu} / \mathrm{ml}\right)$ of a 48 -h-old cells suspension of the yeast species. Incubation and centrifugation were carried out as described earlier, and the supernatant obtained was used to determine the antimicrobial activity as described earlier (Singh et al. 2012). The flask containing sterile basal medium without sodium chloride was inoculated with one $\mathrm{ml}\left(1.0 \times 10^{7} \mathrm{cfu} / \mathrm{ml}\right)$ of a 48-h-old cells suspension of the yeast species and served as the control.

\section{Effect of carbon source on the antimicrobial activity of cell-free metabolite of the yeast species}

The carbon sources used in this study consisted of glucose, fructose, xylose, galactose, lactose, sucrose, maltose, raffinose, sorbitol and mannitol. Fifty mls of the basal medium was dispensed into several 100-ml Erlenmeyer flasks sterilized at $121{ }^{\circ} \mathrm{C}$ for $15 \mathrm{~min}$ and dispensed in equal amount into various test tubes. The carbon sources used were sterilized at $110{ }^{\circ} \mathrm{C}$ for $10 \mathrm{~min}$ and separately aseptically added at $0.8 \%(\mathrm{w} / \mathrm{v})$ concentration to the basal medium in different test tubes and inoculated with one $\left.\mathrm{ml}\left(1.0 \times 10^{7} \mathrm{cfu} / \mathrm{ml}\right)\right)$ of a 48 -h-old cells suspension of the yeast species. Incubation and centrifugation were carried out as described earlier, and the supernatant obtained was used to determine the antimicrobial activity as described earlier (Singh et al. 2012). The flask containing sterile basal medium with no carbon source was inoculated with one $\mathrm{ml}\left(1.0 \times 10^{7} \mathrm{cfu} / \mathrm{ml}\right)$ of a 48 -h-old cells suspension of the yeast species and served as the control.
Effect of nitrogen sources on the antimicrobial activity of the cell-free metabolite of the yeast species

The nitrogen sources used in this study included alanine, aspartic acid, asparagine, tryptophan (simple nitrogen sources), peptone and skimmed milk (complex nitrogen sources). The simple nitrogen sources were supplemented at $0.1 \%$, while the complex nitrogen sources were supplemented at $1 \%$ concentration into the growth medium (Oso 1974). Inoculation, incubation, centrifugation and antimicrobial property were done as reported earlier. The flasks containing basal medium without nitrogen source were inoculated with one $\mathrm{ml}\left(1.0 \times 10^{7} \mathrm{cfu} / \mathrm{ml}\right)$ of a 48 -h-old cells suspension of the yeast species and served as the control.

\section{Determination of minimum inhibitory concentration of supernatant of the yeast species}

The minimum inhibitory concentration (MIC) of the cell-free metabolite of the yeast species was estimated for each of the tested bacteria in triplicate using the broth dilution method described by Singh et al. (2012). Tubes containing double-fold dilution of cellfree metabolite of the yeast species in $1 \mathrm{ml}$ of nutrient broth were inoculated with $1 \mathrm{ml}\left(1.0 \times 10^{7} \mathrm{cfu} / \mathrm{ml}\right)$ of the standardized test bacteria, and a tube containing nutrient broth only was seeded with the test bacteria, which served as control. Incubation was carried out at $37{ }^{\circ} \mathrm{C}$ for $24 \mathrm{~h}$, and the tubes were examined for bacterial growth by viewing turbidity and the test tube that appeared clear/not turbid (no microbial growth) was considered as the MIC. The minimum inhibitory concentration (MIC) was determined as the lowest concentration of the metabolite that showed no visible growth (no turbidity) when compared with the control tube.

\section{Determination of minimum bactericidal concentration of cell-free supernatant of the yeast species}

The minimum bactericidal concentration $(\mathrm{MBC})$ was determined by streaking from each of the MIC (nonturbid) test tubes on nutrient agar and incubated at $37{ }^{\circ} \mathrm{C}$ for $24 \mathrm{~h}$. The lowest concentration of the extract at which the bacteria were killed was regarded as MBC. Each experiment was done in duplicate.

\section{Results}

The result of the frequency of occurrence of the yeast isolates is shown in Table 1. It was observed that a total of seventy-three of the yeast isolates were obtained from the juice of the fruits, and the distribution is shown in Table 1 
Table 1 Frequency of occurrence

\begin{tabular}{ll}
\hline Isolates & $\begin{array}{l}\text { Frequency } \\
\text { of occurrence }\end{array}$ \\
\hline AJ4 Isolate from apple juice & 10 \\
MK4 Isolate obtained from mango juice & 5 \\
PA2 Isolate obtained from pineapple juice & 17 \\
PW1 Isolate obtained from water melon juice & 9 \\
PW4 Isolate obtained from pawpaw juice & 12 \\
OR1 Isolate obtained from cashew juice & 5 \\
OR2 Isolate obtained from orange juice & 15 \\
Total no. of isolates & 73 \\
\hline
\end{tabular}

Table 2 Pathogenicity test of yeast isolates

\begin{tabular}{llll}
\hline Isolate code & $\begin{array}{l}\text { Gelatin } \\
\text { liquefaction }\end{array}$ & Haemolytic test & Dnase test \\
\hline AJ4 & - & - & - \\
MK4 & - & - & - \\
PA2 & - & - & - \\
PW1 & - & - & - \\
PW4 & - & - & - \\
OR1 & - & - & - \\
OR2 & - & - & - \\
\hline
\end{tabular}

- , No activity
The result of the pathogenicity tests conducted on the yeast isolate is shown in Table 2. It can be inferred from the result that all the yeast species tested negative to gelatin liquefaction, haemolytic and DNase tests.

The result of the microscopic morphological appearance of the yeast species shows the shape, colour, elevation, edge, texture, budding cells and appearance of pseudo-hyphae in Table 3. Isolate AJ4 Looks like a creamy flat smooth colony, showing a butyrous texture with single budding. Isolate MK4 was seen under the microscope as a raised ellipsoidal structure with serrated edge. It is mucoid, creamy in colour showing multiple budding with pronounced pseudo-hyphae. Isolate PA2 is a spherically flat structure with smooth edge. It is butyrous and creamy in colour showing single-polar budding. Isolate PW1 was seen in under the microscope as spherical in shape with raised smooth edge, butyrous in nature showing creamy colour and unipolar budding. Isolate PW4 appeared as a flat serrated ellipsoidal-shaped colony, which is butyrous showing single-polar budding with creamy colouration. Isolate ORI was observed under the microscope as a smooth spherically raised creamy colony displaying butyrous texture with unipolar budding. Isolate OR2 was observed under the microscope as a smooth spherically raised pinkish colony displaying butyrous texture accompanied by single budding.

Table 3 Microscopic morphological appearance of the yeast isolates

\begin{tabular}{|c|c|c|c|c|c|c|}
\hline Isolate code & Shape & Elevation & Edge & Texture & Colour & Lactophenol cotton blue \\
\hline AJ4 & Ellipsoidal & Flat & Smooth & Butyrous & Creamy & Single budding cell \\
\hline MK4 & Ellipsoidal & Raise & Serrated & Mucoid & Creamy & $\begin{array}{l}\text { Multiple budding with } \\
\text { pronounced pseudo- } \\
\text { hyphae }\end{array}$ \\
\hline PA2 & Spherical & Flat & Smooth & Butyrous & Creamy & Single-polar budding \\
\hline PW1 & Spherical & Raise & Smooth & Butyrous & Creamy & Unipolar budding \\
\hline Pw4 & Ellipsoidal & Flat & Serrated & Butyrous & Creamy & Singly budding cells \\
\hline OR1 & Spherical & Raise & Smooth & Butyrous & White & Unipolar budding cells \\
\hline OR2 & Spherical & Raise & Smooth & Butyrous & Pinkish & Singly budding \\
\hline
\end{tabular}

\begin{tabular}{|c|c|c|c|c|c|c|c|c|c|c|c|}
\hline & Glucose & Galactose & Sucrose & Fructose & Lactose & Sorbitol & Mannitol & Xylose & Raffinose & Maltose & Probable identity \\
\hline AJ4 (5) & + & +- & +- & +- & +- & +- & + & +- & +- & + & $\begin{array}{l}\text { Candida } \\
\text { pelliculosa }\end{array}$ \\
\hline MK4(8) & ++ & -- & - - & - - & - - & - - & - - & - - & - - & - - & $\begin{array}{l}\text { Kluveromyces } \\
\text { phaffi }\end{array}$ \\
\hline PA2(30) & +- & - & - & + & -- & - & -- & - & ++ & - - & $\begin{array}{l}\text { Metschnikowia } \\
\text { pulcherrima }\end{array}$ \\
\hline WM1(25) & +- & ++ & - & +- & - & - & - & - - & +- & +- & $\begin{array}{l}\text { Saccharomyces cerevisiae } \\
001\end{array}$ \\
\hline PW4(20) & +- & +- & -- & +- & - & - & - & +- & -- & - & $\begin{array}{l}\text { Saccharomyces cerevisiae } \\
002\end{array}$ \\
\hline OR1 & +- & +- & - & +- & -- & - - & -- & +- & -- & - - & 003 \\
\hline 0R2 & +- & +- & - - & +- & - - & - - & - - & +- & - - & -- & Rhodotorula mucilaginosa \\
\hline
\end{tabular}


Figure 1 shows the sugar fermentation pattern of the different yeasts species used in this study. AJ4 utilized glucose, galactose, fructose and maltose but did not utilize raffinose, sucrose, lactose, sorbitol, mannitol, xylose. Isolate MK4 utilized glucose with colour change and gas production, but did not utilize galactose, sucrose, fructose, lactose, sorbitol, mannitol, xylose, maltose and raffinose, while isolate PA2 utilized glucose, fructose with colour change, but no gas production. Raffinose was utilized with colour change and gas production. However, galactose, sucrose, lactose, sorbitol, mannitol, xylose and maltose were not utilized. Isolate PW1 utilized glucose, fructose, raffinose and maltose with colour change, but no gas production. Galactose was utilized with both colour change and gas production. However, sucrose, sorbitol, mannitol, xylose and lactose were not utilized. Isolate PW4 also utilized glucose, galactose, fructose and xylose with colour change but no gas production. The isolate did not utilize sucrose, lactose, sorbitol, mannitol, raffinose and maltose.

OR1 utilized glucose, galactose, fructose and raffinose with colour change, but no gas production but did not utilize sucrose, lactose, sorbitol, mannitol, xylose and maltose.

OR2 did not utilize any of the sugars used in this study. However, isolate AJ4 was able to utilize glucose,

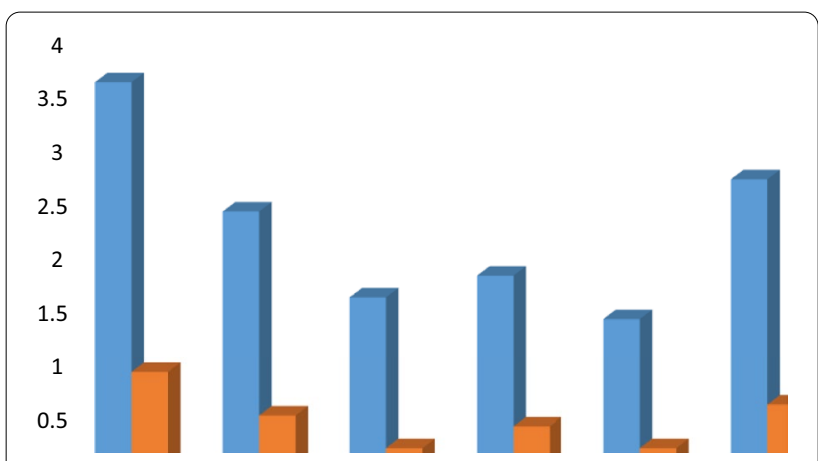

Fig. 2 Quantitative estimation of antimicrobial compounds produced by yeast isolates (lactic acid and diacetyl) galactose, sucrose and maltose with colour change and gas production, but did not utilize fructose, lactose, mannitol, xylose, sorbitol and raffinose.

Results in Fig. 1 were combined together to probably identify isolates AJ4, Mk4, PA2, PW1, PW4, OR1 and OR2, as Candida pelliculosa, kluveromyces phafii, Metschnikowia pulcherrima, Saccharomyces cerevisiae 001, Saccharomyces cerevisiae 002, Saccharomyces cerevisiae.003 and Rhodotorula mucilaginosa, respectively.

The result of quantification of lactic acid and diacetyl produced by the yeast species is presented in Fig. 2. Saccharomyces cerevisiae 001 produced the highest quantity of lactic acid and diacetyl of $3.6 \mathrm{mg} / \mathrm{ml}$ and $1 \mathrm{mg} / \mathrm{ml}$, respectively, while the least quantity of lactic acid was produced by Metschnikowia pulcherrima and the least diacetyl was produced by Candida pelliculosa and Metschnikowia pulcherrima.

The result of the antimicrobial activity of the yeast species against the food-borne pathogens is shown in Table 4. The results obtained showed that the widest zone of inhibition of $25.0 \pm 0.4 \mathrm{~mm}$ was recorded by Saccharomyces cerevisiae (001) against Campylobacter jejuni.

Effect of different $\mathrm{pH}$ on the antimicrobial activities of the yeast species is represented in Fig. $3 a-d$. The pHs used for this study were 3, 4, 5, 6 and 7. The best $\mathrm{pH}$ that favoured the highest inhibitory activity of the cell-free supernatant of the yeast species was 4 at which Saccharomyces cerevisiae 001 showed the highest zone of $30.00 .9 \mathrm{~mm}$ against Campylobacter jejuni, while it showed an inhibition a zone of $25.0 \pm 0.4 \mathrm{~mm}$ against Campylobacter jejuni in the control experiment. The least zone of inhibition at $\mathrm{pH} 4$ was $9.0 \pm 0.3 \mathrm{~mm}$ exhibited by Rhodotorula mucilaginosa against Salmonella sp.

Table $5 \mathrm{a}$ and $\mathrm{b}$ represents the result of effect of different temperatures on the inhibitory activity of the yeast species. The different temperature used in this study included $30{ }^{\circ} \mathrm{C}, 35{ }^{\circ} \mathrm{C}, 40{ }^{\circ} \mathrm{C}$ and $45{ }^{\circ} \mathrm{C}$. The result revealed that the best temperature $\left(30{ }^{\circ} \mathrm{C}\right)$

Table 4 Zone of inhibition of yeast isolates against food-borne pathogens

\begin{tabular}{lllll}
\hline Yeast isolates & Vibro cholerae & Listeria monocytogene & Campylobacter jejuni & Salmonella sp. \\
\hline Candida pelliculosa & - & - & $9.0 \pm 0.02$ & $5.0 \pm 0.5$ \\
Kluyveromyces phaffii & - & - & - & $7.0 \pm 0.2$ \\
Metschnikowia pulcherrima & $11.0 \pm 0.2$ & - & $8.0 \pm 0.5$ & - \\
Saccharomyces cerevisiae001 & - & $18.0 \pm 0.1$ & $25.0 \pm 0.4$ & - \\
Saccharomyces cerevisiae002 & - & $16.0 \pm 0.3$ & 20.0 & $19.0 \pm 0.8$ \\
Saccharomyces cerevisiae003 & $6.0 . \pm 0.1$ & - & - & $13.0 \pm 0.4$ \\
Rhodotorula mucilaginosa & - & - & - & $5.0 . \pm 02$ \\
\hline
\end{tabular}

,- No activity 
a
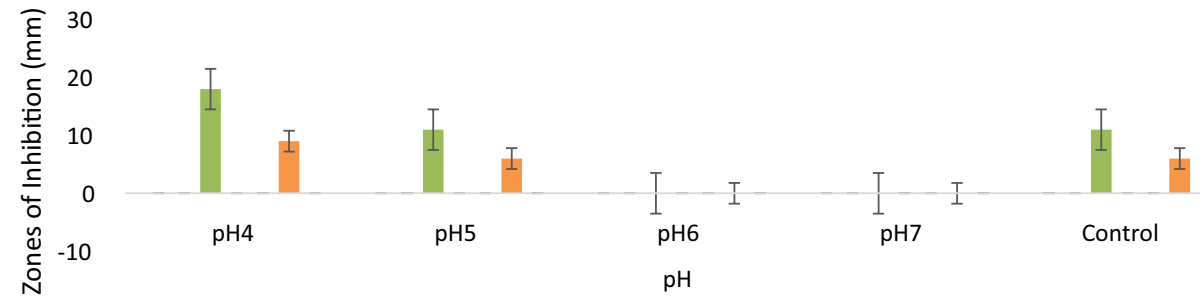

$\mathrm{pH}$
C. pelliculosa
K. Phaffi
M. Pulcherrima
S. cerevisiae001
S. cerevisiae002
S. cerevisiae003
a $\mathrm{R}$

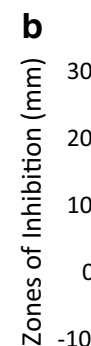

L. Monocytogenes
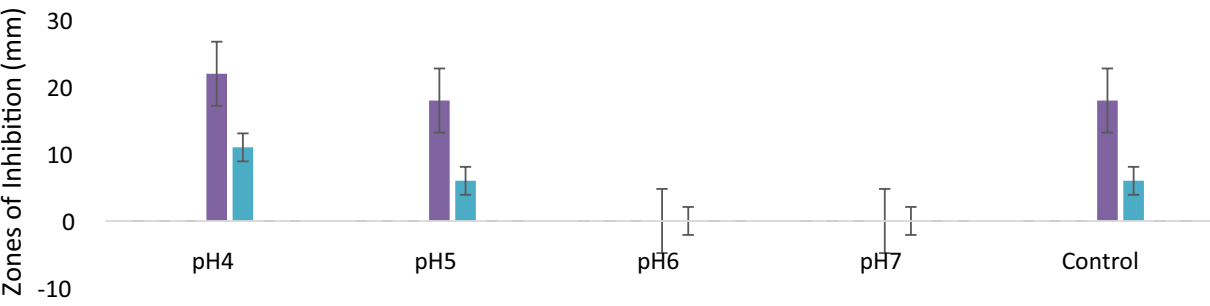

$\mathrm{pH}$
C. pelliculosa
K. Phaffi
M. Pulcherrima
S. cerevisiae001
S. cerevisiae002
S. cerevisiae003

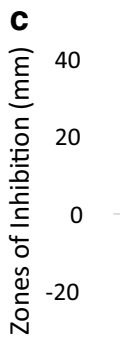

C. Jejuni
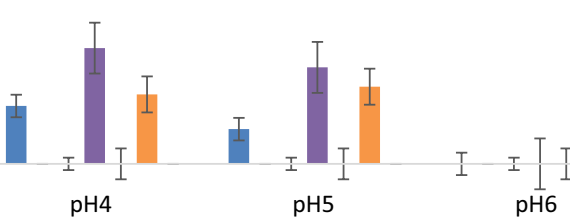

$\mathrm{pH}$
C. pelliculosa
K. Phaffi
M. Pulcherrima
S. cerevisiae001
S. cerevisiae002
S.cerevisieae 003
R. mucilaginosa

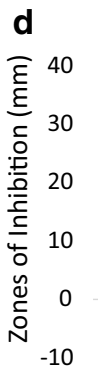

Salmonella sp.
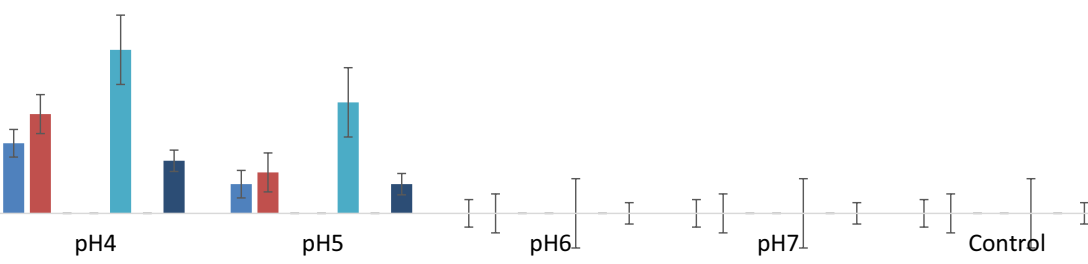

$\mathrm{pH}$

$$
\begin{aligned}
& \square \text { C. pelliculosa } \square \text { K. Phaffi } \square \text { M. Pulcherrima } \square \text { S. cerevisiae001 } \\
& \square \text { S. cerevisiae002 } \approx \text { S.cerevisieae 00? R. mucilaginosa }
\end{aligned}
$$

Fig. 3 a Effect of different $\mathrm{pH}$ on the antimicrobial activities of the yeast species on Vibrio cholerae. $\mathbf{b}$ Effect of different pH on the antimicrobial activities of the yeast species on Listeria monocytogenes. $\mathbf{c}$ Effect of different $\mathrm{pH}$ on the antimicrobial activities of the yeast species on C. jejuni. $\mathbf{d}$ Effect of different $\mathrm{pH}$ on the antimicrobial activities of the yeast species on Salmonella 
Table 5 Effect of temperature on the microbial inhibitory activity $(\mathrm{mm})$ of the yeast species

\begin{tabular}{|c|c|c|c|c|c|c|c|c|}
\hline \multirow[t]{2}{*}{ Yeast species } & \multicolumn{4}{|c|}{ Vibrio cholera } & \multicolumn{4}{|c|}{ Listeria monocytogenes } \\
\hline & $30^{\circ} \mathrm{C}$ & $35^{\circ} \mathrm{C}$ & $40^{\circ} \mathrm{C}$ & $45^{\circ} \mathrm{C}$ & $30^{\circ} \mathrm{C}$ & $35^{\circ} \mathrm{C}$ & $40^{\circ} \mathrm{C}$ & $45^{\circ} \mathrm{C}$ \\
\hline \multicolumn{9}{|l|}{ (a) } \\
\hline Candida pelliculosa & - & - & - & - & - & - & - & - \\
\hline K.phaffii & 8.0 & - & - & - & - & - & - & - \\
\hline M. pulcherrium & $11 \pm 0.7$ & - & - & - & - & - & - & - \\
\hline S. cerevisiae 001 & - & - & - & - & 18.0 & - & - & - \\
\hline S. cerevisiae 002 & - & - & - & - & 16.0 & 20.0 & - & - \\
\hline S. cerevisiae 003 & $6.0 \pm 0.3$ & - & - & - & - & - & - & - \\
\hline R. mucilaginosa & - & - & - & - & - & - & - & - \\
\hline \multirow[t]{2}{*}{ Yeast species } & \multicolumn{4}{|c|}{ Campylobacter jejuni } & \multicolumn{4}{|c|}{ Salmonella sp. } \\
\hline & $30^{\circ} \mathrm{C}$ & $35^{\circ} \mathrm{C}$ & $40^{\circ} \mathrm{C}$ & $45^{\circ} \mathrm{C}$ & $30^{\circ} \mathrm{C}$ & $35^{\circ} \mathrm{C}$ & $40^{\circ} \mathrm{C}$ & $45^{\circ} \mathrm{C}$ \\
\hline \multicolumn{9}{|l|}{ (b) } \\
\hline Candida pelliculosa & $9.0 \pm 0.3$ & - & - & - & $5.0 \pm 0.2$ & - & - & - \\
\hline K.phaffii & - & - & - & - & $7.0 \pm 0.4$ & - & - & - \\
\hline M. pulcherrium & 8.0 & - & - & - & - & - & - & - \\
\hline S. cerevisiae 001 & $25 \pm 0.3$ & - & - & - & - & - & - & - \\
\hline S. cerevisiae 002 & - & - & - & - & 19.0 & - & - & - \\
\hline S. cerevisiae 003 & - & - & - & - & 13.0 & - & - & - \\
\hline R. mucilaginosa & - & - & - & - & $5.0 \pm 0.1$ & - & - & - \\
\hline
\end{tabular}

\section{Table 6 Effect of salt concentration on the antimicrobial activities of yeast species}

Zone of inhibition (mm)

\begin{tabular}{|c|c|c|c|c|c|c|c|c|c|c|c|c|}
\hline \multirow[t]{2}{*}{ Salt conc. (\%) } & \multicolumn{4}{|c|}{ C. palicullosa } & \multicolumn{4}{|l|}{ K. phaffii } & \multicolumn{4}{|c|}{ M. pulcherima } \\
\hline & V.C & L.M & C.J & $\mathrm{S}$ & V.C & L.M & C.J & $\mathrm{S}$ & V.C & L.M & C.J & $\mathrm{S}$ \\
\hline $2 \%$ & - & - & - & - & $2.0 \pm 0.1$ & - & - & $3.0 \pm 0.1$ & $2.0 \pm 0.1$ & - & - & $2.0 \pm 0.3$ \\
\hline $4 \%$ & - & - & - & - & - & - & - & - & - & - & - & - \\
\hline $6 \%$ & - & - & - & - & - & - & - & - & - & - & - & - \\
\hline Control & - & - & $9.0 \pm 0.2$ & $5.0 \pm 0.3$ & - & - & - & $7.0 \pm 0.2$ & $11.0 \pm 0.2$ & - & $8.0 \pm 0.5$ & - \\
\hline
\end{tabular}

Salmonella sp (S.S), Campylobacter jejuni (C.J), Listeria monocytogenes (L.M) and Vibrio cholera (V.C)

- , No activity

that supported the maximum inhibition zone of $25.0 \pm 0.3 \mathrm{~mm}$ was recorded by Saccharomyces cerevisiae 001 against Campylobacter jejuni (Table 5b).

The result of the effect of different sodium chloride concentrations on the antimicrobial activity of yeast species is displayed in Table 6 and Fig. 4a-e. It was observed that $2 \%$ sodium chloride concentration stimulated the highest inhibitory performance of $5.0 \pm 0.0 .1 \mathrm{~mm}$ produced by Saccharomyces cerevisiae 002 against Campylobacter jejuni.

The result of the effect of carbon sources on the antimicrobial activity of yeast species is presented in Table 7 and Fig. $5 \mathrm{a}-\mathrm{d}$. The result showed that the supplementation of glucose in the growth medium supported the best antimicrobial activity of the yeast species against yeast species with the highest inhibition zone of $19.0 \pm 0.1 \mathrm{~mm}$ produced by S. cerevisiae 001 against Campylobacter jejuni, which was lower than the inhibition zone recorded in the control.

The result of the effect of nitrogen sources on the antimicrobial activity of the yeast species against the test bacteria is shown in Table $8 \mathrm{a}, \mathrm{b}$ and c. It was observed that the supplementation of skimmed milk in the growth medium favoured the best antimicrobial activity of the yeast species with the highest inhibition zone of $27.0 \pm 0.2 \mathrm{~m}$ recorded by Saccharomyces 001 against 
a

Sacharomyces cerevisae 001

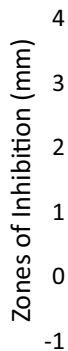

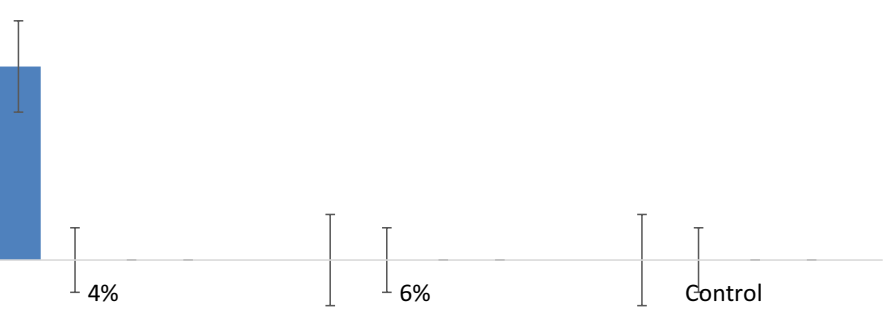

Percent salt concentration

$\square . C \backsim$ L.M $\square$ C.J $\square$ S.S

b

Sacharomyces cerevisae 002

30

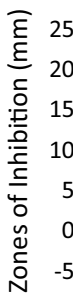
5

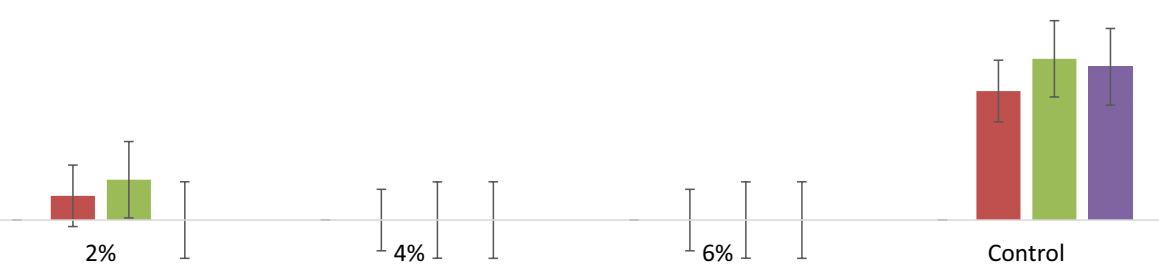

$-10$

Percent Salt Concentration

$\square$ V.C $\square$ L.M $\backsim$ C.J $\backsim$ S.S

C

Sacharomyces cerevisae 003

20

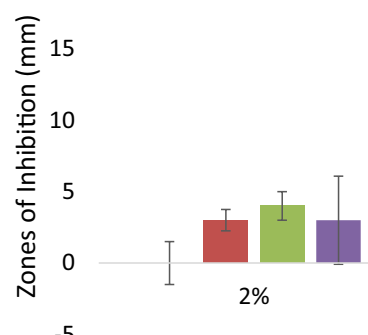

$-5$

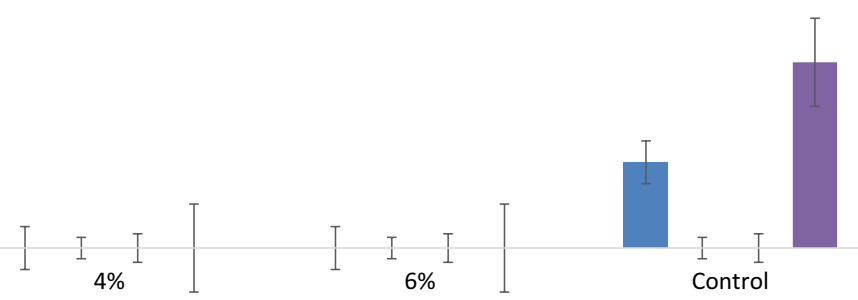

Percent Salt Concentration

$\square \mathrm{V} . \mathrm{C} \backsim \mathrm{L} . \mathrm{M} \backsim \mathrm{C} . J \backsim \mathrm{S} . \mathrm{S}$

d

Rodotorula mucilaginous

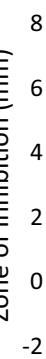

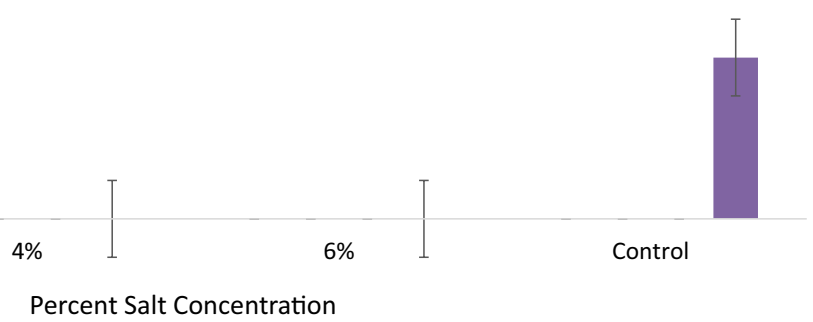

$\square$ V.C $\square$ L.M $\backsim$ C.J $\backsim$ S.S

Fig. 4 a Effect of salt concentration on the antimicrobial activity of Saccharomyces cerevisiae. $\mathbf{b}$ Effect of salt concentration on the antimicrobial activity of Saccharomyces cerevisiae 002. c Effect of salt concentration on the antimicrobial activity of Saccharomyces cerevisiae 00. $\mathbf{d}$ Effect of salt concentration on the antimicrobial activity of Rhodotorula mucilaginosa. e Effect of salt concentration on the antimicrobial activity of Rhodotorula mucilaginosa 


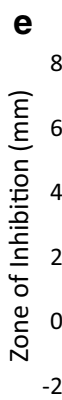

Rodotorula mucilaginous 8

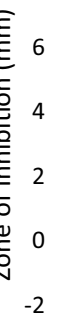

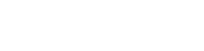

Fig. 4 continued

Table 7 Effects of carbon source on the antimicrobial activities of yeast isolates

\begin{tabular}{|c|c|c|c|c|c|c|c|c|c|c|c|c|}
\hline \multicolumn{13}{|c|}{ Zone of inhibition (mm) } \\
\hline \multirow[t]{2}{*}{ Carbon sources } & \multicolumn{4}{|c|}{ Candida pelliculosa } & \multicolumn{4}{|c|}{ Kluyveromyces phaffii } & \multicolumn{4}{|c|}{ Metschnikowia pulcherrima } \\
\hline & V.C & L.M & C.J & S.S & V.C & L.M & C.J & S.S & V.C & L.M & C.J & $S$ \\
\hline Glucose & $5.0 \pm 0.2$ & 6.0 & $14.0 \pm 0.6$ & 7.0 & $5.0 \pm 0.3$ & $4.0 \pm 0.5$ & $2.0 \pm 0.1$ & $6.0 \pm 0.2$ & - & - & - & $6.0 \pm 0.1$ \\
\hline Sucrose & - & $7.0 \pm 0.7$ & $13.0 \pm 0.2$ & $6.0 \pm 0.3$ & $2.0 \pm 0.2$ & - & - & $4.0 \pm 0.4$ & $4.0 \pm 0.1$ & 6.0 & $2.0 \pm 0.1$ & $7.0 \pm 0.2$ \\
\hline Fructose & - & 5.0 & $11.0 \pm 0.1$ & $5.0 \pm 0.1$ & $2.0 \pm 0.1$ & - & $3.0 \pm 0.1$ & - & - & & - & $5.0 \pm 0.3$ \\
\hline Maltose & - & $5.0 \pm 0.3$ & $12.0 \pm 0.6$ & $8.0 \pm 0.5$ & - & - & - & - & - & - & - & 5.0 \\
\hline Mannitol & - & $4.0 \pm 0.7$ & - & $2.0 \pm 0.2$ & - & $2.0 \pm 0.1$ & - & - & - & - & 2.0 & $4.0 \pm 0.6$ \\
\hline Sorbitol & - & $18.0 \pm 0.3$ & $6.0 \pm 0.1$ & - & - & - & - & - & - & - & - & $18 \pm 0.6$ \\
\hline Xylose & - & $11.0 \pm 0.2$ & - & - & - & - & - & - & - & - & - & $11 \pm 0.1$ \\
\hline Raffinose & - & - & - & - & - & - & - & - & - & - & - & - \\
\hline Control & - & - & $9.0 \pm 0.6$ & $5.0 \pm 0.5$ & - & - & - & $7.0 \pm 0.9$ & $11.0 \pm 0.2$ & - & $8.0 \pm 0.4$ & - \\
\hline
\end{tabular}

Salmonella sp (S.S), Campylobacter jejuni (C.J), Listeria monocytogenes (L.M) and Vibrio cholera (V.C)

- , No activity

Campylobacter jejuni (Table 8b), while an inhibition of $25 \mathrm{~mm}$ was observed in the control.

The result of the minimum inhibitory concentration is presented in Table 9. The lowest MIC values of $25.0 \pm 0.9$ and $25.0 \pm 0.8 \mu \mathrm{g} / \mathrm{ml}$ were recorded by Candida pelliculosa and Rhodotorula mucilaginosa, respectively, against Salmoella sp. The highest MIC values of $3.125 \pm 0.6 \mu \mathrm{g} /$ $\mathrm{ml}$ and $3.125 \pm 0.3 \mu \mathrm{g} / \mathrm{ml}$ were exhibited by Saccharomyces cerevisiae 001 against L. Monocytogenes and C. jejuni. The result of the minimum bactericidal concentration is presented in Table 10. The least MBC values of $6.25 \pm 0.2$ and $6.25 \pm 0.3$ were recorded by Saccharomyces cerevisiae 001 against L. Monocytogenes and Campylobacter jejuni, respectively.

Figure 6 shows the zone on inhibition of Kluyveromyces phaffii on Vibrio cholera, while Fig. 7 depicts the antagonistic effect of Metschnikowia pulcherrima (white arrow),
Saccharomyces cerevisiae 001 (red arrow) \& 003 (blue arrow) against Vibrio cholerae.

Antagonistic effect of Metschnikowia pulcherrima on Salmonella sp. is shown in Fig. 8, while Fig. 9 represents the effect of Candida pelliculosa on Campylobacter jejuni at $\mathrm{pH} 4$.

\section{Discussion}

In this present study, isolation and identification of yeast species and their antimicrobial activity against food-borne pathogens were determined. In addition, effects of some cultural conditions on the inhibitory activity of the yeast species against some selected food-borne pathogens were evaluated. The isolation and identification of yeast species from fruits had been previously documented by Alakeji et al. (2015), Ogunremi et al. (2015), Sulieman et al. (2015), Zerihun (2016) and Fakruddin et al. (2017). Their existence in fruits, fermented foods and beverages is depended on 
a Sacharomyces cerevisae 001

a

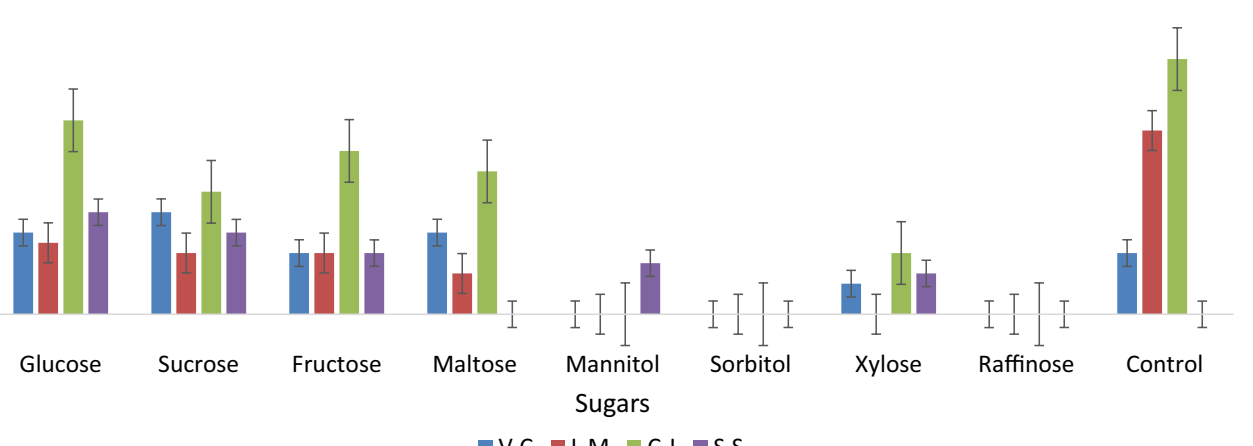

$\backsim$ V.C $\square$ L.M $\backsim$ C.J $\backsim$ S.S

b

Sacharomyces cerevisae 002

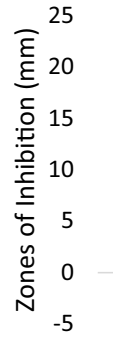

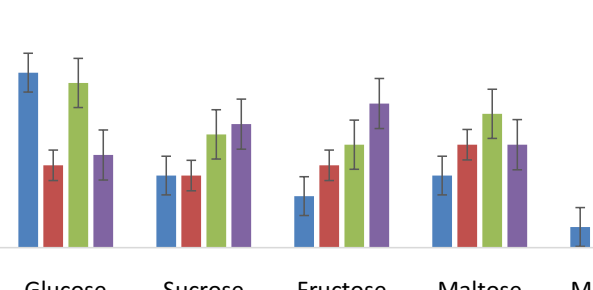

Glucose Sucrose

Fructose

Maltose

Mannitol

Sugars

$\square$ V.C $\square$ L.M $\square$ C.J $\square$ S.S

C

Sacharomyces cerevisae 003

16
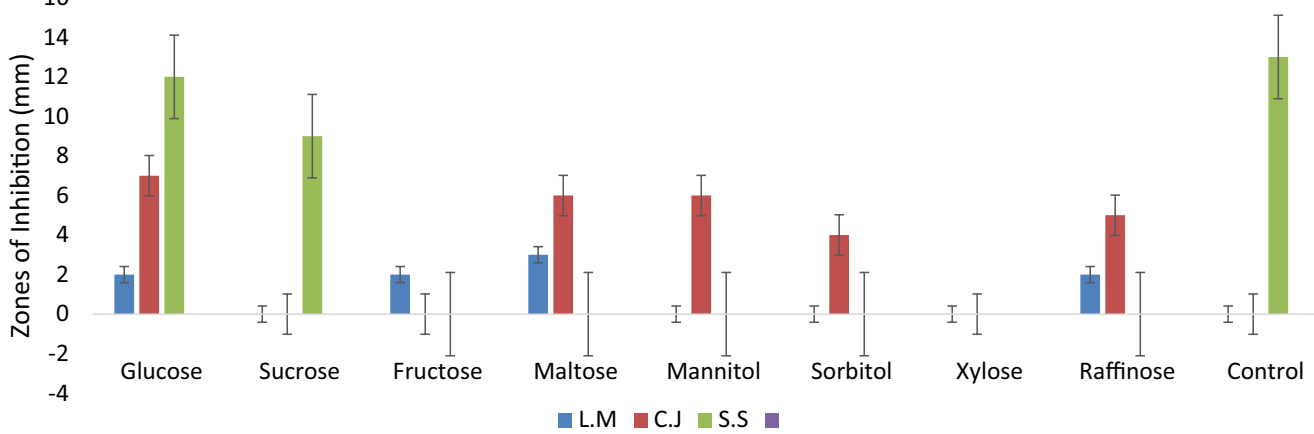

d

Rhodotorula mucilaginosa

14

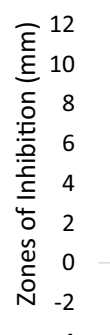
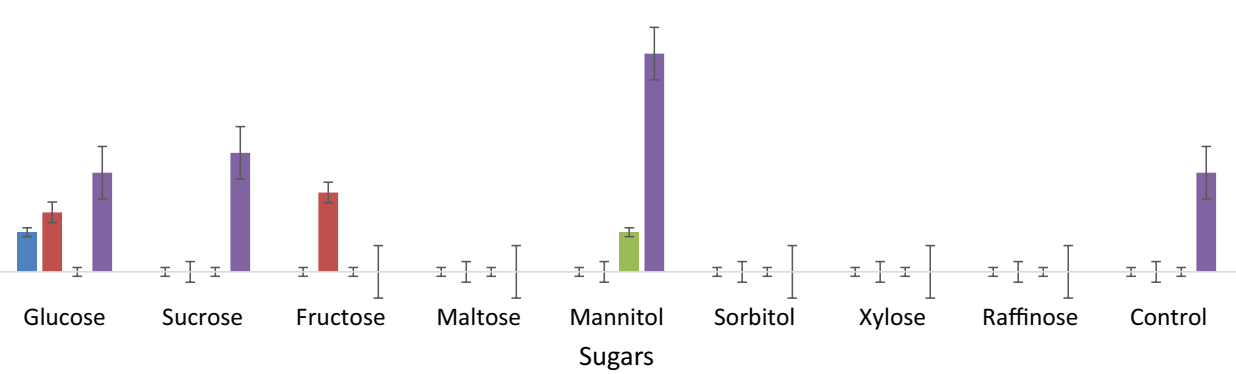

$\square$ V.C $\square$ L.M $\square$ C.J $\square$ S.S

Fig. 5 a Effect of carbon sources on the antimicrobial activities of Saccharomyces cerevisiae 001. b Effect of carbon sources on the antimicrobial activities of Saccharomyces cerevisiae 002. c Effect of carbon source on the antimicrobial activities of Saccharomyces cerevisiae 003. $\mathbf{d}$ Effect of carbon source on the antimicrobial activities of Rhodotorula mucilaginosa 
Table 8 Effect of nitrogen sources on the antimicrobial activities of $(a)$ yeast species, $(b, c)$ yeast isolates

\begin{tabular}{|c|c|c|c|c|c|c|c|c|c|c|c|c|}
\hline \multirow[t]{2}{*}{ Nitrogen sources } & \multicolumn{4}{|c|}{ Candida pelliculosa } & \multicolumn{4}{|c|}{ Kluyveromyces phaffii } & \multicolumn{4}{|c|}{ Metschnikowia pulcherrima } \\
\hline & V.C & L.M & C.J & S.S & V.C & L.M & C.J & S.S & V.C & L.M & C.J & $S$ \\
\hline \multicolumn{13}{|l|}{ (a) } \\
\hline Alanine & - & $5.0 \pm 0.3$ & $5.0 \pm 0.1$ & $7.0 \pm 0.2$ & $2.0 \pm 0.2$ & 7.0 & $2.0 \pm 0.1$ & $3.0 \pm 0.1$ & 10.0 & - & $9.0 \pm 0.2$ & $4.0 \pm 0.4$ \\
\hline Aspartic acid & $4.0 \pm 0.3$ & - & - & $3.0 \pm 0.2$ & - & $7.0 \pm 0.6$ & - & $2.0 \pm 0.1$ & - & $2.0 \pm 0.1$ & - & - \\
\hline Asparagine & $4.0 \pm 0.4$ & $2.0 \pm 0.1$ & $2.0 \pm 0.1$ & - & - & - & - & - & $15.0 \pm 0.8$ & - & $5.0 \pm 0.6$ & $4.0 \pm 0.1$ \\
\hline Peptone & - & - & - & $6.0 \pm 0.4$ & $5.0 \pm 0.5$ & 10.00 & $4.0 \pm 0.4$ & $6.0 \pm 0.2$ & 10.0 & - & - & - \\
\hline Skimmed milk & $2.0 \pm 0.1$ & $6.0 \pm 0.2$ & $3.0 \pm 0.1$ & $5.0 \pm 0.3$ & $2.0 \pm 0.1$ & $9.0 \pm 0.2$ & $2.0 \pm 0.1$ & $3.0 \pm 0.1$ & 12.0 & 2.0 & $2.0 \pm 0.1$ & $6.0 \pm 0.2$ \\
\hline Tryptophan & \multirow{2}{*}{-} & - & - & $6.0 \pm 0.1$ & - & - & $2.0 \pm 0.1$ & - & $9.0 \pm 0.5$ & - & - & - \\
\hline Control & & - & $9.0 \pm 0.5$ & $5.0 \pm 0.2$ & - & - & - & $7.0 \pm 0.4$ & $11.0 \pm 0.7$ & - & $8.0 \pm 0.8$ & - \\
\hline \multirow[t]{2}{*}{ Nitrogen sources } & \multicolumn{6}{|c|}{ Saccharomyces cerevisiae 001} & \multicolumn{6}{|c|}{ Saccharomyces cerevisiae 002} \\
\hline & \multicolumn{2}{|l|}{ V.C } & L.M & \multicolumn{2}{|l|}{ C.J } & S.S & \multicolumn{2}{|l|}{ V.C } & L.M & \multicolumn{2}{|l|}{ C.J } & S.S \\
\hline \multicolumn{13}{|l|}{ (b) } \\
\hline Alanine & \multicolumn{2}{|c|}{$5.0 \pm 0.3$} & $16 \pm 0.3$ & \multicolumn{2}{|c|}{$23 \pm 0.7$} & $5.0 \pm 0.1$ & \multicolumn{2}{|l|}{2.0} & $17.0 \pm 0.6$ & \multicolumn{2}{|c|}{$21.0 \pm 0.1$} & $17.0 \pm 0.1$ \\
\hline Aspartic acid & $7.0 \pm$ & 0.1 & 15.0 & $24.0 \pm$ & 0.1 & $3.0 \pm 0.1$ & - & & 19.0 & 22.0 & & $14.0 \pm 0.3$ \\
\hline Asparagine & $6.0 \pm$ & 0.1 & 10.0 & 24.0 & & - & - & & $5.0 \pm 0.1$ & $11.0 \pm$ & 0.3 & 10.0 \\
\hline Peptone & $5.0 \pm$ & 0.2 & $12 \pm 0.1$ & 21.0 & & - & $9.0 \pm$ & 0.3 & - & $19.0 \pm$ & 0.2 & 10.0 \\
\hline Skimmed milk & $4.0 \pm$ & 0.1 & $8 \pm 0.2$ & $27 \pm 0$ & & 2.0 & $7.0 \pm$ & & 20.0 & $17.0 \pm$ & 0.1 & $21.0 \pm 0.1$ \\
\hline Tryptophan & 5.0 & & $11 \pm 0.3$ & $20 \pm 0$ & & - & $5.0 \pm$ & & $19.0 \pm 0.5$ & $19.0 \pm$ & 0.3 & $15.0 \pm 0.6$ \\
\hline Control & - & & $18 \pm 0.1$ & $25 \pm 0$ & & - & 0.2 & & $16.0 \pm 0.1$ & 20.0 & & 19.0 \\
\hline Nitrogen sources & $\mathrm{Sac}$ & haromyce & es cerevisia & 003 & & & & Rhodotor & ula mucilagi & inous & & \\
\hline & V.C & & L.M & C. & & S.S & & V.C & L.M & & C.J & S.S \\
\hline (c) & & & & & & & & & & & & \\
\hline Alanine & $7.0=$ & $=0.1$ & $2.0 \pm 0.1$ & & \pm 0.1 & $12.0 \pm$ & & - & $5.0 \pm C$ & & $5.0 \pm 0.1$ & 16.0 \\
\hline Aspartic acid & - & & - & - & & 10.0 & & - & $4.0 \pm C$ & & 7.0 & 15 \\
\hline Asparagine & - & & - & - & & - & & $3.0 \pm 0.1$ & - & & $6.0 \pm 0.2$ & 10 \\
\hline Peptone & - & & - & - & & - & & $5.0 \pm 0.3$ & $9.0 \pm c$ & & $5.0 \pm 0.1$ & 12.0 \\
\hline Skimmed milk & 12.0 & \pm 0.5 & 2.0 & & \pm 0.2 & $11.0 \pm$ & & $4.0 \pm 0.1$ & $7.0 \pm 0$ & & $4.0 \pm 0.1$ & 8.0 \\
\hline Tryptophan & $7.0=$ & $=0.5$ & - & & $0 \pm 0.1$ & $13.0 \pm$ & & - & $4.0 \pm C$ & & - & - \\
\hline Control & $6.0=$ & $=0.4$ & - & - & & 13.0 & & - & - & & - & 5.0 \\
\hline
\end{tabular}

Salmonella sp (S.S), Campylobacter jejuni (C.J), Listeria monocytogenes (L.M) and Vibrio cholera (V.C)

- , No activity

Table 9 Minimum inhibitory concentration $(\mu \mathrm{g} / \mathrm{ml})$ of yeast isolates against test organisms

\begin{tabular}{lllll}
\hline Yeast species & Vibro cholera & L. Monocytogenes & Campylobacter jejuni & Salmonella sp \\
\hline Candida pelliculosa & - & - & $6.25 \pm 0.8$ & $25 \pm 0.9$ \\
Kluyveromyces phaffii & - & - & - & $12.5 \pm 0.7$ \\
Metschnikowia pulcherrima & $6.25 \pm 0.2$ & - & $3.125 \pm 0.3$ & - \\
Saccharomyces cerevisiae 001 & $12.5 \pm 0.3$ & $3.125 \pm 0.6$ & - & - \\
Saccharomyces cerevisiae 002 & $12.5 \pm 0.8$ & - & - & - \\
Saccharomyces cerevisiae 003 & $12.5 \pm 0.5$ & - & - & $25.0 \pm 0.1$ \\
Rhodotorula mucilaginosa & - & - & & -
\end{tabular}

- , No activity 
Table 10 Minimum bactericidal concentration $(\mu \mathrm{g} / \mathrm{ml})$ of yeast supernatant against test bacteria

\begin{tabular}{lllll}
\hline Isolates code & Vibro cholera & L. Monocytogenes & C. jejuni & Salmonella spp. \\
\hline Candida palliculosa & - & - & $1.2 .5 \pm 0.2$ & 50.0 \\
Kluyveromyces phaffii & - & - & - & $25.0 \pm 0.5$ \\
Metschnikowia pulcherrima & $12.5 \pm 0.2$ & - & $25.5 \pm 0.5$ & - \\
Saccharomyces cerevisiae 001 & $25.0 \pm 0.2$ & $-25 \pm 0.2$ & - & - \\
Saccharomyces cerevisiae 002 & $25.0 \pm 0.5$ & - & - & $12.5 \pm 0.3$ \\
Saccharomyces cerevisiae 003 & $25.0 \pm 0.3$ & - & - & - \\
Rhodotorula mucilaginous & - & - & 50.0 \\
\hline
\end{tabular}

-, No activity

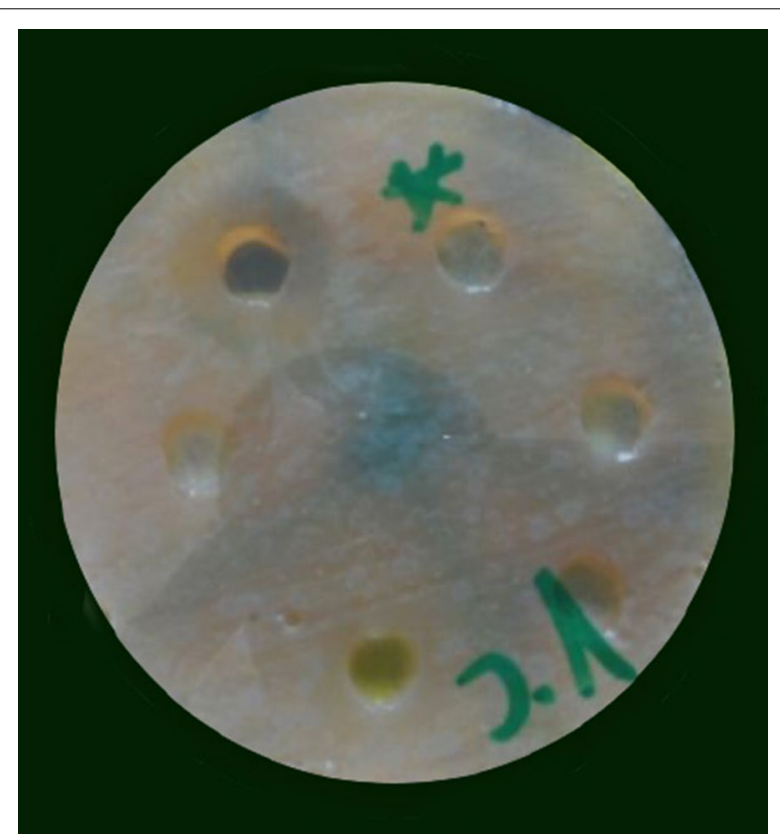

Fig. 6 Inhibition of Kluyveromyces phaffii on Vibrio cholerae

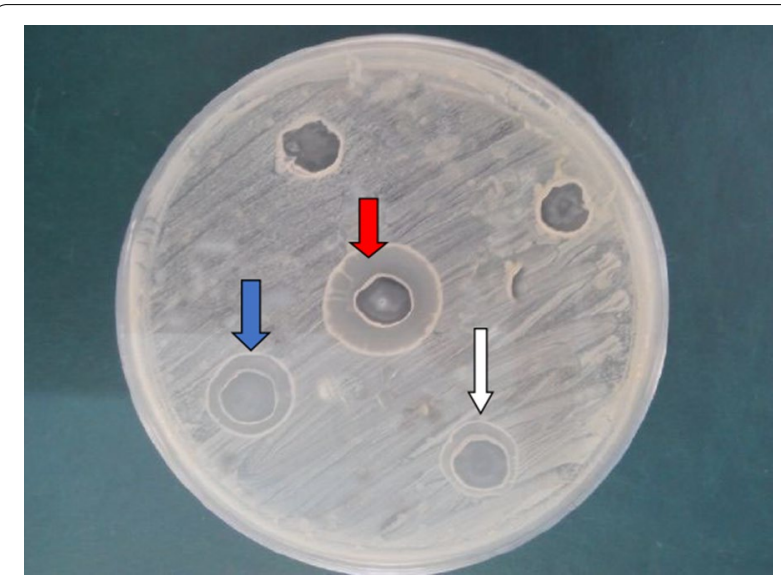

Fig. 7 Antagonistic effect of Metschnikowia pulcherrima (white arrow), Saccharomyces cerevisiae 001 (red arrow) \& 003 (blue arrow) against Vibrio cholerae

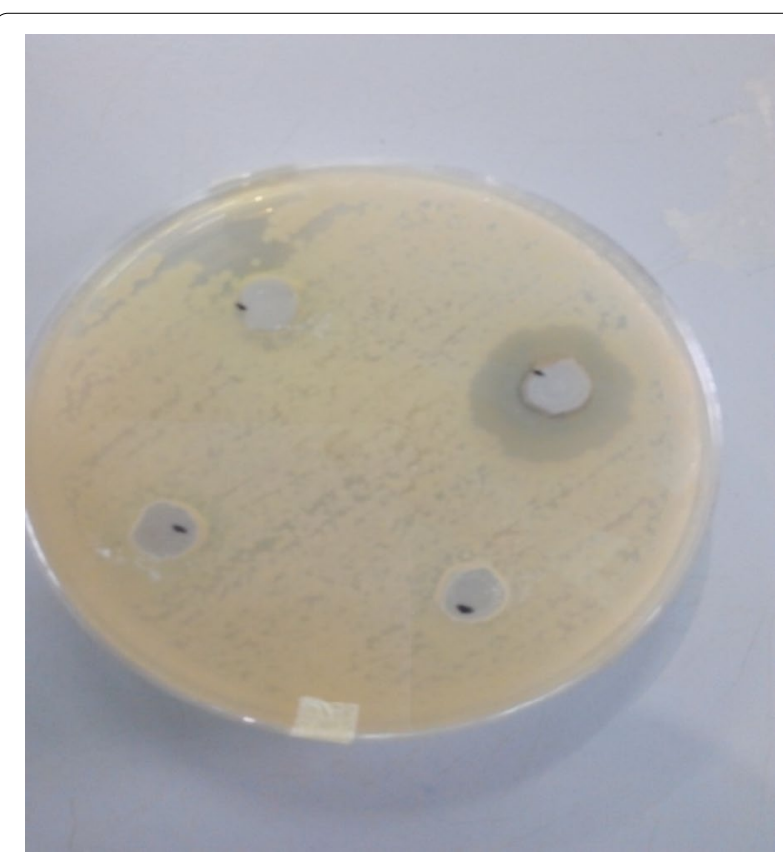

Fig. 8 Antagonistic effect of Metschnikowia pulcherrima on Salmonella sp

to their high affinity for sugar, their fermentative ability and adaptation to the prevailing conditions in the food matrix and utilization of the nutrients present in the substrate for growth and metabolism.

The identification procedure was carried out by considering their ability to ferment different sugars and nitrogen assimilation test. Sanni (1993), Alakeji et al. (2015) and Fakruddin et al. (2017) had earlier reported the identification of yeast species from traditionally fermented cereal-based products. The diversity of yeast from different fruits as observed in this study is similar to the earlier reports of Sanni and Lonner (1993), Pedersen et al. (2012), Alakeji et al. (2015) and Ogunremi et al. (2015), and reasons such as different geographical location and methods of processing might be adduced 


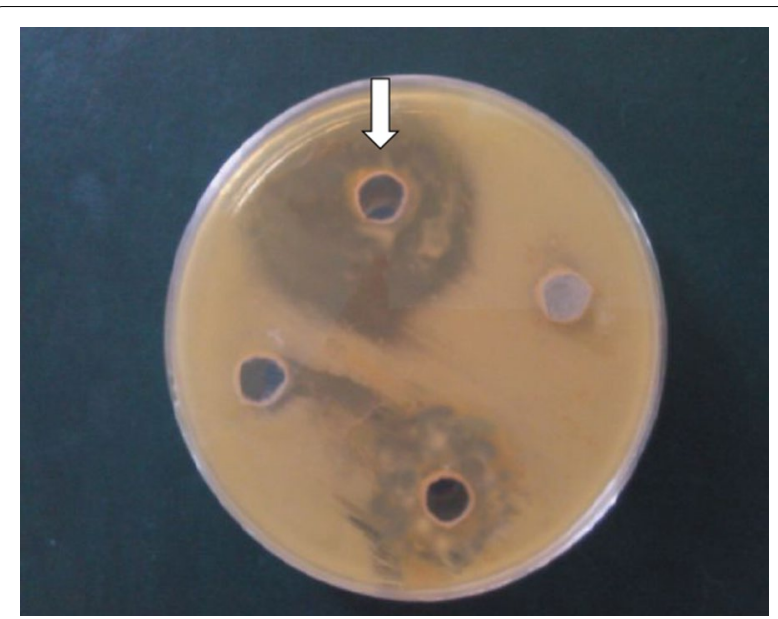

Fig. 9 Antagonistic effect of Candida pelliculosa (arrow) on Campylobacter jejuni at $\mathrm{pH} 4$

to be responsible for such occurrences (Sanni and Lonner 1993).

The safety of yeast species has been reported since time immemorial, which confirms their suitability as starter culture in food fermentation. Bourdichon et al. (2012) reported that food-grade yeasts must not be pathogenic as they are generally regarded as safe (GRAS).

The yeast species tested in this present study revealed that the all produce lactic acid and diacetyl in varying quantities. The production of inhibitory secondary metabolites by yeast had been previously documented (Marquina et al. 2002; Viljoen 2006). The ability of the yeast species to inhibit the test bacteria is highly dependent on the production of inhibitory metabolites. In addition, it is reported that the inhibitory activity of yeast species had been exploited in bio-control of diseases, probiotic applications, treatment of microbial infections and biotechnological processes (Hatoum et al. 2012). The mechanism of action of the secondary inhibitory compounds produced by yeast species involves changes in the structure and rigidity of the cell wall, thereby causing its dissolution (Dieuleveux et al. 1998).

The inhibitory activity of yeast species against foodborne pathogens observed in this study had been previously reported by Roostita et al. (2011), Younis et al. (2017) and Fakruddin et al. (2017). The ability of the yeast species to inhibit the test bacteria might be due to the production of extracellular protease, secretion of inhibitory proteins, stimulation of immunoglobulin A, acquisition and elimination of secreted toxins, killer toxins or mycocins, sulphur dioxide, hydrogen peroxide, organic acid, volatile acids (Marquina et al. 2002; Viljoen 2006), competition for nutrient, $\mathrm{pH}$ changes and production of organic acids (Sigler and Höfer 1991; Buyuksirit and
Kuleasan 2014). The mechanism of action of the secondary inhibitory compounds produced by yeast species involves changes in the structure and rigidity of the cell wall, thereby causing its dissolution (Dieuleveux et al. 1998). It is pertinent to note that the inhibition produced by the yeast species depends on both the antimicrobial compounds secreted by the yeast species and test bacteria (Sousa et al. 2012). It can be inferred from this phenomenon that there is a possible occurrence of a specific strain-dependent antimicrobial effect by the yeast species (Aigner et al. 2006).

In addition, it is observed that the antimicrobial activity of yeast species had been exploited in bio-control of diseases, probiotic applications, treatment of microbial infections and biotechnological processes (Hatoum et al. 2012). According to Czerucka and Rampal (2002), Saccharmyces boulardii had been implicated in the prevention of intestinal infections caused by Escheria coli, Staphylococcus aureus, Pseudomonas aeruginosa, Proteus vulgaris, Yesinia enterolica and Candida albican. It is also reported that yeast species with resistant traits to antibiotic are very useful in patient receiving antibiotic treatment (Syal and Vohra 2013). The occurrence of low inhibition exhibited by the supernatant of yeast species might infer that the antimicrobial compounds are not extra cellular secreted but cell bound (Georges et al. 2006). In this present study, it was discovered that the yeast species exhibited antimicrobial activity against all the test gram-positive bacteria, but there are reports of inhibition by yeast cell-free supernatant against grampositive and gram-negative bacteria (Abdelatif et al. 2016). This reported observation is not in agreement with the earlier report of Izgu and Altinbay (1997) who explained that antimicrobial compounds of yeast are only active against gram-positive bacteria.

In addition, Janisiewicz (2010) reported that M. pulcherrima is an important yeast antagonist for inhibiting food-borne bacteria on freshly cut fruits based on the possession of pulcherrimin pigment, while Leverentz et al. (2006) confirmed that M. pulcherrima did not only prevent the growth, but it even reduced populations of the food-borne pathogens on freshly cut apples. Its inhibitory effects extend to many unrelated species including C. albicans.

The highest inhibition zone was recorded at $\mathrm{pH}$ of 4 , and increasing $\mathrm{pH}$ beyond this point showed a reduction in the antimicrobial activities of the yeast metabolites. It could be suggested that high $\mathrm{pH}$ value repressed antibacterial activity of the yeast metabolite (Ohenhen et al. 2015). This finding is in conformity with the earlier reports of Richard and Dale (1984), Fadahunsi et al. (2013) and Yoon et al. (2013). However, Soares and Sato (2000) and Al-Qaysi et al. (2017) reported the maximum 
activity of Saccharomyces cerevisiae at $\mathrm{pH}$ range of 4.14.5 , and this phenomenon might be caused by increased cell surface permeability, resulting in rapid diffusion of nutrients into the cells, which led to increase in the production of antimicrobial substances. In addition, Daeschel and Nes (1991) and Ohenhen et al. (2015) explained that this observation might be caused by the ability of the microorganisms to exhibit a high tolerance at low $\mathrm{pH}$ and cell wall membrane physiology. This finding is contrary to the submission of Ohenhen et al. (2015) who reported that diluted crude bacteriocin extract isolated from Lactobacillus plantarum exhibited high antimicrobial activity at $\mathrm{pH} 2$ compared to the antimicrobial activity displayed at pH 4, 6 and 8. Saliani et al. (2014) reported higher $\mathrm{pH}$ values inhibited bacterial growth by binding to the outside of the bacteria, permeabilizing the outer membrane and disrupting the cytoplasmic membrane. The results obtained in this study showed that the highest zone of inhibition was observed at $30{ }^{\circ} \mathrm{C}$. The observation is in agreement with the submission of Barnett et al. (2000) who reported optimal growth temperature of yeasts between the range of $25-30{ }^{\circ} \mathrm{C}$, and this observation might be responsible for the highest zones of inhibition observed at $30{ }^{\circ} \mathrm{C}$. This apparent expression of antibacterial activity of the yeast metabolites at $30{ }^{\circ} \mathrm{C}$ could suggest its stability at this temperature, which negates the findings of Sah et al. (2012) who reported that minimal antibacterial activity of extract was recorded at ambient temperature $\left(28 \pm 2{ }^{\circ} \mathrm{C}\right)$. According to Durairaj et al. (2009), the reduction in antimicrobial activity of natural products by heating may be due to volatilization and/or the physical and chemical changes that occur during heating; this submission confirmed the earlier report of Sah et al. (2012) who observed that increasing temperature deteriorated the antibacterial properties of ginger drastically. The effect of increasing temperature showed a decrease in antimicrobial activity and that the zones of inhibition recorded were different for the different yeast species; this finding is similar to the earlier reports of Hajdu (2010) who discovered that increase in temperature to $45^{\circ} \mathrm{C}$, for a prolonged period, may result in thermal burn injuries, while Murray et al. (2003) stated that temperature is a basic requirement for bacterial growth.

The maximum antimicrobial activity of the yeast cell supernatant was enhanced at $2 \%$ and $4 \% \mathrm{NaCl}$ concentration, and beyond this point zero activity was recorded. Similar observation had earlier been reported by Yoon et al. (2013), and the reduced activity recorded might due to $\mathrm{NaCl}$ effect (Hong et al. 2014). Yoon et al. (2013) reported that increase in $\mathrm{NaCl}$ concentration decreased antibiotic susceptibility of bacteria to eight antibiotics, and the exposure of bacteria to $\mathrm{NaCl}$ may cause variation in antibiotic sensitivity of the bacteria, but the effect of $\mathrm{NaCl}$ on sensitivity of bacteria strains to antibiotic is dependent on both the strain and the antibiotic agent. It was further stated that $\mathrm{NaCl}$ might be responsible for increased thermal resistance, cell invasion efficiency and antibiotic resistance of the test bacteria in the food matrix (Yoon et al. 2013). The repression caused by the application of $\mathrm{NaCl}$ to antimicrobial sensitivity is linked to Rpos, a general stress response regulator, which is unregulated when bacteria are exposed to osmotic stress, and concluded that $\mathrm{NaCl}$ may regulate Rpos expression, thereby affecting antimicrobial sensitivity of bacteria (HenggeAronis 2002; Huang et al. 2009). In addition, according to Brejovah (1997), the decrease in the antimicrobial activity due to the effect of sodium chloride at higher concentration in the cultivation medium might have emanated from changes in the composition of extracellular yeast glycoprotein. This report agrees with the earlier findings of Blomberg (2000) who explained that high $\mathrm{NaCl}$ concentration imposes both ionic and hyperosmotic stress on yeast cells. However, Al-Qaysi et al. (2017) reported that the maximum antimicrobial activity of killer toxin was recorded at $8 \%$ sodium chloride concentration, while the least occurred at $2 \%$, which is inconsistent with the findings of this present investigation.

The highest zone of inhibition was produced when glucose was supplemented into growth medium as the only carbon source, while raffinose stimulated the least. This observation is inconsistent with the submission of Bhattachryya et al. (1998) who revealed that glycerol supported better antibiotic production by Streptomyces hygroscopicus. It was observed that a high degree of variation was observed in the level of antimicrobial activity when the different carbon sources were tested in the medium. It is suggested that the effect of carbon sources on antimicrobial activity is strain dependent. This observation is consistent with the findings of Slininger and Shea-Wilbur (1991) and El-Barnna (2005) who reported that antimicrobial activity of C. xerosis NB-2 was highly induced by glucose, and less activity was observed with maltose, sucrose, galactose, ribose, fructose, arabinose and glycerol. According to Gallo and Katz (1972) and Haavik (1974), the presence of glucose in the growth medium is an excellent carbon source for growth because the yeast readily utilizes monosaccharaides as the sole carbon sources for their metabolism and interferes with the biosynthesis of many antimicrobial agents such as bacitracin and actinomycin. In addition, glucose is considered the main carbon source by all microorganisms due to its size, rapid uptake, utilization and cellular energy conversion (Buchmanan and Stahl 1984; Roitman et al 1990; Calvo et al. 2002). It is suggested that changes in the fermentation medium development show better positive influence than glucose as carbon sources for 
antibiotic production, and nutritional and environmental factors exhibit paramount influence on antibiotic production (El-Barnna 2005). Glucose was also reported as the most suitable carbon source for maximum phenazine production by Pseudomonas fluorescens 2-79Q (Slininger and Shea-wilbur 1995). It is pertinent to note that the knowledge of the effect of nutritional composition on antimicrobial substances production could be exploited in process optimization of the production of antimicrobial substances.

The effect of nitrogen sources on the antimicrobial activity of the yeast isolates in this study showed that the highest antimicrobial activity was recorded when skimmed milk was supplemented differently in the growth medium as the sole nitrogen source. There is dearth of available information on the conformity of this finding with previous related existing literature. However, some authors had earlier reported sodium nitrate stimulating the highest activity, Gogoi et al. (2008a, b) reported that ammonium nitrate as nitrogen source promoted the biosynthesis of secondary metabolite, Mahalaxmi et al. (2010) reported similar results for rifamycin B production under SSF using corn husk and wheat bran as the substrate, Ramos and Said (2011) reported that the biosynthesis of secondary metabolites is influenced by cellular condition and that the source of nitrogen is important for the production of antibiotic substances (Demain 1999).

The MIC values of the yeast species metabolites for the test bacteria revealed a pronounced variation. This varying tend is an indication that the MIC values are depended on both the yeast and the test bacteria. The MIC values of the yeast metabolite are measures of potency of the yeast metabolite. Low MIC values indicate high degree of potency of the yeast metabolites, while high MIC values indicate low degree of potency. It is observed that the low MIC and higher MBC values recorded by the metabolites indicated that they are bacteriostatic at lower concentrations and bactericidal at higher concentration (Rahman et al. 2011). It could be suggested that it can be used to inhibit food-borne pathogenic bacteria and be applied in food preservation, biocontrol, probiotics application and control of microbial infections. It is pertinent to report that MIC data are very crucial because they can be used as reference point in the treatment of bacterial infections (Aboaba et al. 2011). In addition, it is also observed that the ratios of $\mathrm{MBC} / \mathrm{MIC}$ were less than or equal to 4 , and according to Tepe et al. (2004), the existence of such ratios revealed that the yeast metabolites are bactericidal.

\section{Conclusion}

This study confirmed the antimicrobial activity of yeast metabolites against food-borne pathogens; therefore, based on the production of inhibitory substances they can be considered as a good candidate for use in food preservation.

\section{Abbreviations}

MIC: Minimum inhibitory concentration; MBC: Minimum bactericidal concentration; GIT: Gastrointestinal tract; YEPD: Yeast extract peptone dextrose.

Acknowledgements

Not applicable.

\section{Authors' contributions}

IFF designed, conceptualized and supervised the study. SO carried out the experimental protocols and assays. IFF wrote the first draft. The authors read and approved the final manuscript.

Funding

This research was self-funded.

Availability of data and materials

All data generated or analysed during this study are included in this article.

Ethics approval and consent to participate

Not applicable.

Consent for publication

Not applicable.

Competing interests

No competing interest exists in the research outcome presented in this article.

Received: 28 October 2020 Accepted: 29 December 2020

Published online: 03 February 2021

\footnotetext{
References

Abdelatif SS, Elsayed SM, Bahout AA, Bayoumi AM (2016) Studies on beneficial yeasts isolated from some Egyptian dairy products. Zagazig Vet J 44(1):75-84

Aboaba OO, Ezeh AR, Anabuike CL (2011) Antimicrobial activities of some Nigerian spices on some pathogens. Agric Biol J N Am 2:1187-1193

Aigner U, Goerges S, Silakowski B, Scherer S (2006) Inhibition of Listeria monocytogenes by food-borne yeasts. Appl Environ Microbiol 72(1):313-318

Akinjogunla OJ, Ajayi AO, Ekeh NO (2014) Virulence factors and antibiotic resistant Staphylococcus spp from the anteriornares of apparently healthy undergraduate students in uyo. Am J Res Com 2(11):158-180

Alakeji TP, Banwo K, Ogunremi OR, Sanni Al (2015) Functional properties of yeasts isolated from some Nigerian traditional fermented foods. J Microbiol Biotechnol Food Sci 4(5):437-444

Al-Qaysi SA, Al-Haideri H, Thabit ZA, Al-Kubaisy WH, Ibrahim JA (2017) Production, characterization, and antimicrobial activity of mycocin produced by Debaryomyces hansenii DSMZ70238. Int J Microbiol 2605382

AOAC (2003) Official Method of analysis, 17th edn. Association of Official Analytical Chemistry, Washington, p 24

Arthu H, Watson K (1976) Thermal adaptation in yeast: growth temperature, membrane lipid, and cytochrome composition of psychrophilic, mesophilic and thermophilic yeast. J Bacteriol 128(1):56-68

Balasubramania MK, Bi E, Glover M (2004) Comparative analysis of cytokinesis in budding, fission yeast and animal cells. Curr Biol 14(18):R806-R818

Barnett JA, Payne RW, Yaeeow D (2000) Yeast characteristics and identification, 3rd edn. Cambridge University Press, London
} 
Bhalodia NR, Shulka VJ (2011) Antibacteria and antifungal activites from leaf extacts of Cassia fistula 1. An ethno medicinal plant. J Adv Pharm Technol Res 2:106-109

Bhattachryya B, Sushil P, Sukanta S (1998) Antibiotic production by Streptomyces hygroscopicus D 1.5: cultural effect. Rev Microbiol 29(3):3714

Blomberg A (2000) Metabolic surprises in Saccharomyces cerevisiae during adaptation to saline conditions: questions, some answers and a model FEMS. Microbiol Lett 182(1):1-8

Boone C, Sdicu A, Degri R, Sanchez C, Bussey H (1990) Integration of the yeast "KI" killer toxin in gene into the genome of marked wine yeasts and its effect on vinification. Yeast 41:37-42

Bourdichon F, Casaregola S, Farrokh C, Frisvad JC, Gerds ML, Hammes WP, Harnett J, Huys G (2012) Food fermentations: microorganisms with technological beneficial use. Int J Food Microbiol 154:87-97

Buchmanan RL, Stahl TS (1984) Ability of various carbon sources to induce and support aflatoxin biosynthesis by Aspergillus parasiticus. J Food Saf 6:271-279

Buyuksirit T, Kuleasan H (2014) Antimicrobial agents produced by yeasts. Int J Biol Biomol Agric Food Biotechnol Eng 8(10):1013-1016

Cailliez JC, Seguy N, Aliouat EM, Polonelli L, Camus D (1994) The yeast killer phenomenon, hypothetical way to control Pneumocytosis carinii pneumonia. Med Hypo 43:167-171

Calvo AM, Wilson AR, Bok JW, Keller NP (2002) Relationship between secondary metabolites and fungal development. Microbiol Mol Biol Rev 66:447-459

Chiquette J (2009) Evaluation of the protective effect of probiotics fed to dairy cows during a sub-acute ruminal acidosis challenge. Anim Feed Sci Technol 153:278-291

Comitini F, De IJ, Pepe L, Mannazzu I, Ciani M (2004a) Pichia anomala and Kluyveromyces wickerhamii killer toxins as new tools against Dekkeral Brettanomyces spoilage yeasts. FEMS Microbiol Lett 238:235-240

Comitini F, Pietro ND, Zacchi L, Mannazzu I, Ciani M (2004b) Kluyveromyces phaffii killer toxin active against wine spoilage: purification and characterization. Microbiology 150:2535-2541

Czerucka D, Rampal P (2002) Experimental effects of Saccharomyces boulardii on diarrheal pathogens. Microbes Infect 4:733-739

Czerucka D, Piche T, Rampal P (2007) Review article: yeast as probioticsSaccharomyces boulardii. Aliment Pharmacol Ther 26:767-778

D'Souza AL, Rajkumar C, Cooke J, Bulpitt CJ (2002) Probiotics in prevention of antibiotic associated diarrhoea: meta-analysis. Br Med J 324:1-6

Daeschel MA, Nes IF (1991) Lactobacillusplantarum: physiology, genetics and applications in foods. In: Hui YH, Khachatourians GG (eds) Food biotechnology. VCH Verlagsgesellschaft $\mathrm{mbH}$, Weinheim

Deak T (2006) Environmental factors influencing yeasts. In: Péter G, Rosa C (eds) Biodiversity and ecophysiology of yeasts (the yeast hand book series). Springer, Berlin, pp 155-174

Demain AL (1999) Pharmaceutically active secondary metabo-lites of microorganisms. Appl Microbiol Biotechnol 52:455-463

Dieuleveux V, Van Der Pyl D, Chataud J, Gueguen M (1998) Purification and characterization of anti-Listeria compounds produced by Geotrichum candidum. Appl Environ Microbiol 64:800-803

Druvefors UA, Passoth V, Schurer J (2005) Nutrient effect on biocontrol of Penicillium roqueforti by Pichia anomola J121 during airtight storage of wheat. Appl Environ Microbiol 71:1865-1869

Durairaj S, Srinivasan S, Lakshmanaperumalsamy P (2009) In vitro antibacterial activity and stability of garlic extract at different ph and temperature. Electr J Biol 5(1):5-10

El-Banna N (2005) A study on the antimicrobial activity of Corynebacterium kutscheri isolated from Jordanian soil. Umm Al-Qura. Univ J Sci Med Eng 17:127-135

El-Banna NM (2006) Effect of carbon source on the antimicrobial activity of Corynebacterium kutscheri and Corynebacterium xerosis. Afr J Biotechnol 5(10):833-835

El-neshawy SM, Wilson CL (1997) Nisin enhancement of biocontrol of postharvest diseases of apple with Candida oleophila. Postharvest Biol Technol 10:9-14

Fadahunsi IF, Ogunbanwo ST, Ogundana DT (2013) Heat stability and optimization of invitro antimicrobial activity of metabolites produced by Rhizopus oligosporus NRRL against some selected food-borne pathogens. Trachia J Sci 11(2):110-117
Fakruddin M, Hossain MN, Ahmed MM (2017) Antimicrobial and antioxidant activities of Saccharomyces cerevisiae IFST062013, a potential probiotic. BMC Complement Altern Med 17:64-73

Fernández AJ, Ata-Ali J, Alegre-Domingo T, Candel-Martí E, Ata-Ali F, Palacio JR, Peñarrocha-Diago M (2015) The effect of orally administered probiotic Lactobacillus reuteri-containing tablets in peri-implant mucositis: a double-blind randomized controlled trial. J Periodontal Res 50(6):775-785

Gallo M, Katz E (1972) Regulation of secondary metabolite biosynthesis. Catabolite repression of phenoxazone synthase and actinomycin formation by glucose. J Bacteriol 109:659-667

Generoso SV, Viana M, Santos R, Martins FS, Machado JA, Arantes RM, Nicoli JR, Correia MI, Cardoso VN (2010) Saccharomyces cerevisiae strain UFMG 905 protects against bacterial translocation, preserves gut barrier integrity and stimulates the immune system in a murine intestinal obstruction model. Arch Microbiol 192:477-484

Georges S, Aigner U, Silakowski B, Scherer S (2006) Inhibition of Listeria monocytogenes by food borne-yeasts. Appl Environ Microbiol 72(1):313-318

Gogoi DK, Deka Boruah HP, Saikia R, Bora TC (2008a) Optimization of process parameters for improved production of bioactive metabolite by a novel endophytic fungus Fusarium sp. DF2 isolated from Taxus wallichiana of North East India. World J Microbiol Biotechnol 24:79-87

Gogoi DK, Mazumder S, Saikia R, Bora TC (2008b) Impact of submerged culture conditions on growth and bioactivemetabolite produced by endophyte Hypocrea spp. NSF-08 isolated from Dillenia indica Linn. in North-East India. J Med Myco 18:1-9

Goldman E (2008) Practical handbook of microbiology, 2nd edn. CRC Press, Boca Raton

Haavik H (1974) Studies on the formation of bacitracin in Bacillus licheniformis: effect of glucose. J Gen Microbiol 81:383-390

Hajdu S, Holinka J, Reichmann S, Hirschl AM, Graninger W, Prester E (2010) Increased temperature enhances the antimicrobial effects of daptomycin, vancomycin, tigecycline, fosfomycin, and cefamandole on staphylococcal biofilms. Antimicrobial Agents Chemother 54:4078-4084

Hara S, limura Y, Otsuka K (1980) Breeding of useful killer wine yeasts. Am J Enol Vitic 31:28-33

Hatoum R, Labrie S, Fliss I (2012) Antimicrobial and probiotic properties of yeasts: from fundamental to novel applications. Front Microbiol 3:421-427

Hengge-Aronis R (2002) Signal transduction and regulatory mechanisms involved in control of the os (RpoS) subunit of RNA polymerase. Microbiol Mol Biol Rev 66(3):373-395

Herrera CM, Canto A, Pozo M, Bazaga P (2010) In hospitable sweetness: nectar filtering of pollinator-borne inocula leads to impoverished Phylogenetically clustered yeast communities. Proc R Soc B 277(1682):745-754

Hodgson VJ, Button D, Walker GM (1995) Anti-candida activity of a novel killer toxin from the yeast Williopsis mrakii. Microbiology 141:2003-2012

Hong Y, Kim H, Bang H, Kim M, Kim IT, Park Y, Chung D (2014) Effects of NaCl and organic acids on the antimicrobial activity of Chitosan K Korean. $J$ Microbiol Biotechnol 42:413-415

Huang Y, Kan B, Lu Y (2009) The effect of osmotic shock onRpoS expression and antibiotic resistance in Escherichia coli. J Exp Microbiol Immunol 13(1):13-17

Izgu F, Altinbay D (1997) Killer toxins of certain yeast strains have potential growth inhibitory activity on gram-positive pathogenic bacteria. Microbiology 89:15-22

Janisiewicz WJ (2010) Quo vadis of biological control of postharvest diseases. Postharvest Pathol 2:137-148

Katakura Y, Sano R, Hashimoto T, Ninomiya K, Shioya S (2010) Lactic acid bacteria display on the cell surface cytosolic proteins that recognize yeast mannan. Appl Microbiol Biotechnol 86:319-326

Kelsesidis T, Pothoulakis C (2012) Efficacy and safety of the probiotic Saccharomyces boulardii for the prevention \& therapy of gastro intestinal disorders. Ther Adv Gastroenterol 5(2):111-125

Klingberg TD, Axelsson L, Naterstad K, Elsser D, Budde BB (2005) Identification of potential probiotic starter cultures for Scandinavian-type fermented sausages. Int J Food Microbiol 105:419-431

Kumura H, Tanoune Y, Tsukahara M, Tanaka T, Shimazki K (2014) Screening of dairy yeast strain and their potential probiotic application. J Dairy Sci 87:4050-4056

Kurtzman CP, Fell JW, Boekhout T (2010) Definition, classification and nomenclature of the yeasts. In: The yeasts a taxonomic study, 5th edn 
Kurtzman CP, Fell JW, Boekhout T (2011) The yeasts: a taxonomic study. Elsevier, Amsterdam

Kutty SN, Philip S (2008) Marine yeasts—a review. Yeast 25:465-483

Leverentz B, Conway WS, Janisiewicz W, Abadias M, Kurtzman CP, Camp MJ (2006) Biocontrol of the food-borne pathogens Listeria monocytogenes and Salmonella enterica Serovar poona on fresh-cut apples with naturally occurring bacterial and yeast antagonists. Appl Environ Microbiol 72:1135-1140

Maccaferri S, Klinder A, Brigidi P, Cavina P, Costabile A (2012) Potential probiotic Kluyveromyces marxianus B0399 modulates the immune response in Caco-2 cells and peripheral blood mononuclear cells and impacts the human gut microbiota in an in vitro colonic model system. Appl Environ Microbiol 78:956-964

Mahalaxmi Y, Sathish T, Subba Rao CH, Prakasham RS (2010) Corn husk as a novel substrate for the production ofrifamycin B by isolated Amycolatopsis sp. RSP 3 under SSF. Pro Biochem 45:47-53

Marquina D, Santos A, Peinado JM (2002) Biology of killer yeasts. Int Microbio $5: 65-71$

Martin J, Demain A (1980) Control of antibiotic biosynthesis. Microbiol Rev 44:230-251

Meynell GG, Meynell E (1965) Theory of practice of experimental bacteriology. Cambridge University Press, Cambridge

Murray PR, Baron EJ, Jorgensen JH, Pfaller MA, Yolken RH (2003) Manual of clinical microbiology, 8th edn. ASM Press, Washington

Ogunremi OR, Sanni Al, Agrawal R (2015) Probiotic potentials of yeasts isolated from some cereal-based Nigerian traditional fermented food products. J Appl Microbiol 119:797-808

Ohenhen RE, Isibor JO, Emonfonmwan G, Enabulele SA (2015) Effects of $\mathrm{PH}$ and storage temperatures on antibacterial activity of bacteriocin produced by lactic acid bacteria isolated from OGI. Br Microbiol Res J 9(3):1-9

Olutiola PO, Famurewa O, Sonntag HG (1991) An introduction to general microbiology. A practical approach, 1st edn. Heidelberger Verlagsanstalt, Heldelberg, pp 157-180

Oso BA (1974) Utilisation of lipids as sole carbon sources by thermophilic fungi. Z Allg Mikro/Jiol 14:713-717

O'Sullivan L, Murphy B, McLoughlin P, Duggan P, Lawlor PG, Hughes H, Gardiner GE (2010) Prebiotics from marine macroalgae for human and animal health applications. Mar Drugs. 8:2038-2064

Oyewole OB (1997) Lactic fermented foods in Africa and their benefits. Food Control 8:289-297

Palpacelli V, Ciani M, Rosini G (1991) Activity of different "killer"yeasts on strains of yeast species undesirable in the food industry. FEMS Microbiol Lett 68:75-78

Pedersen LL, Owusu-Kwarteng J, Thorsen L, Jespersen L (2012) Biodiversity and probiotic potential of yeasts isolated from Fura, a West African spontaneously fermented cereal. Int J Food Microbiol 159:144-151

Pfeiffer P, Radler F (1984) Comparison of the killer toxin of several yeasts and the purification of a toxin of type K2. Arch Microbiol 137:357-361

Polonelli L, Morace G (1986) Re-evaluation of the yeast killer phenomenon. J Clin Microbiol 24:866-869

Polonelli L, Lorenzini R, De Bernardis F, Morace G (1986) Potential therapeutic effect of yeast killer toxin. Mycopathologia 96:103-107

Polonelli L, Magliani W, Ciociola T, Giovati L, Conti S (2011) From Pichia anomala killer toxin through killer antibodies to killer peptides for a comprehensive anti-infective strategy. Antonie Van Leeuwenhoek 99:35-41

Pretorius IS (2000) Tailoring wine yeast for the new millennium: novel approaches to the ancient art of winemaking. Yeast 16:675-729

Psani M, Kotzekidou P (2006) Technological characteristics of yeast strains and their potential as starter adjuncts in Greek-style black olive fermentation. World J Microbiol Biotechnol 22:1329-1336

Rahman MS, Satehin MF, Jamal MA, Pravin HM, Alam A (2011) Antibacterial activity of Argemone mexicana L. against water borne microbes. Res $J$ Med Plant 5(5):621-626

Ramos HP, Said S (2011) Modulation of biological activities Produced by an endophytic fungus under different cultureconditions. Adv Biosci Biotechnol 2:443-449

Richard DM, Dale WG (1984) Germination of Khizopus oligosporus sporangiospore. Appl Environ Microbiol 24:1067-1074
Roitman J, Mahoney N, Janisiewicz W (1990) Production and composition of phenylpyrrole metabolites produced by Pseudomona cepacia. Appl Microbiol Biotechnol 34:381-386

Roostita LB, Fleet GH, Wendry SP, Apon ZM, Gemilang LU (2011) Determination of yeasts antimicrobial activity in milk and meat products. Adv J Food Sci Technol 3(6):442-445

Sah P, Al-Tamimi BNA, Al-Mamari R (2012) Effect of temperature on antibiotic properties of garlic (Allium sativum L.) and ginger (Zingiber officinale Rosc.). Afr J Biotechnol 11(95):16192-16195

Saliani M, Jalal R, Kafshdare EG (2015) Effects of pH and temperature on antibacterial activity of zinc oxide nanofluid against Escherichia coliO157: H7 and Staphylococcus aureus. Jundishapur J Microbiol 8(2):e17115

Sanni Al (1993) The need for process optimization of African fermented foods and beverages. Int J Food Microbiol 18:85-95

Sanni Al, Lonner C (1993) Identification of yeasts isolated from Nigerian traditional alcoholic beverages. Food Microbiol 10:517-523

Santos A, Marquina D (2004) Killer toxin of Pichia membranifaciens and its possible use as a biocontrol agent against grey mould disease of grapevine. Microbiology 150:2527-2534

Seki T, Choi EH, Ryu D (1985) Construction of killer wine yeast strain. App Environ Microbiol 49:1211-1215

Sigler K, Höfer M (1991) Mechanisms of acid extrusion in yeast. Biochem Biophys Acta 1071(4):375-391

Singh R, Gaur R, Tiwari S, Gaur MK (2012) Production of pollulan by a thermotolerant Aureobasidium polullan strain in non stirred fed batch fermentation. Process Braz J Microbiol 43:1042-1050

Slavikova E, Vadkertova R, Vianova D (2007) Yeast colonizing leaf surface. J Basic Microbiol 47(4):344-350

Slininger P, Shea-Wilbur M (1995) Liquid-culture pH, temperature, and carbon (not nitrogen) source regulate phenazine productivity of take-all biocontrol agent Pseudomonas fluorescens 2-79. Appl Microbiol Biotechnol 43:794-800

Soares GAM, Sato HH (2000) Characterization of the Saccharomyces cerevisae Y500-4L killer toxin. Braz J Microbiol 31(4):291-297

Sousa MJ, Ludovico P, Rodrigues F, Leao C, Corte-Real M (2012) Stress and cell death in yeast induced by acetic acid. In: Bubulya P (ed) Cell metabolism - cell homeostasis and stress response. InTech, London, pp 73-100

Sousa AM, Machado I, Nicolau A, Pereira MO (2013) Improvements on colony morphology identification towards bacterial profiling. J Microbiol Methods 95(3):327-335

Suharaja AS, Henriksson A, Lin SQ (2012) Impact of Saccharomyces cerevisiae on viability of probiotic Lactobacillus rhamnosus in termented milk under ambient conditions. J Food Process Preserv 10:1748-4549

Sulieman AE, Esra AM, Abdelgadir WS (2015) Isolation and identification of yeasts from the different stages of Hulu-mur fermentation. J Microbiol Res 5(2):71-76

Syal P, Vohra A (2013) Probiotic potential of yeasts isolated from traditional indian fermented foods. Intl J Microbiol Res 5(2):390-398

Tepe B, Daferera D, Soklmen M, Polissiou M, Sokmen M (2004) In vitro antimicrobial and antioxidant activity of the essential oils and various extracts of Thymus eigil M Zohary et P.H. Davis. J Agric Food Chem 52:1132-1137

Van Vuuren HJ, Jacobs CJ (1992) Killer yeasts in the wine industry: a review. Am $J$ Enol Vitic 43:119-128

Viljoen B (2006) Yeast ecological interactions. Yeast'yeast, yeast' bacteria, yeast' fungi interactions and yeasts as biocontrol agents. In: Querol A, Fleet G (eds) Yeasts in food and beverages. Springer, Berlin, pp 83-110

Walt JP, Yarrow D (1984) Methods for the isolation, maintenance, classification and identification of yeasts. In: Kreger-van Rij NJW (ed) The yeasts-a taxonomic study, 3rd edn. Elsevier, Amsterdam, pp 45-104

Yoon JH, Park B, Oh M, Choi K, YohanYoon Y (2013) Effect of $\mathrm{NaCl}$ on heat resistance, antibiotic susceptibility, and caco-2 cell invasion of Salmonella. BioMed Res Int 5:1155/274096

Young TW, Yagiu M (1978) A comparison of the killer character in different yeasts and its classification. AntonieVanLeeuwenhoek 44:59-77

Younis G, Awad A, Mohamed N (2017) Phenotypic and genotypic characterization of antimicrobial susceptibility of avian pathogenic Escherichia coli isolated from broiler chickens. Vet World 10(10):1167-1172

Zerihun T (2016) Isolation, identification and characterization of ethanol tolerant yeast species from fruits for production of bio-ethanol. Int J Mod Chem Appl Sci 3(3):437-443 
Zhao S, Guo Y, Wang Q, Luo H, He C, An B (2020) Expression of flagellin at yeast surface increases biocontrol efficiency of yeast cells against postharvest disease of tomato caused by Botrytis cinerea. Postharvest Biol Technol $162: 1-15$

\section{Publisher's Note}

Springer Nature remains neutral with regard to jurisdictional claims in published maps and institutional affiliations.
Submit your manuscript to a SpringerOpen ${ }^{\odot}$ journal and benefit from:

- Convenient online submission

- Rigorous peer review

- Open access: articles freely available online

- High visibility within the field

- Retaining the copyright to your article

Submit your next manuscript at $\boldsymbol{\nabla}$ springeropen.com 